\title{
An improved parameterisation of ozone dry deposition to the ocean and its impact in a global climate-chemistry model
}

\author{
Ashok K. Luhar, Ian E. Galbally, Matthew T. Woodhouse, and Marcus Thatcher \\ CSIRO Oceans and Atmosphere, Aspendale, 3195, Australia \\ Correspondence to: Ashok K. Luhar (ashok.luhar@csiro.au)
}

Received: 22 September 2016 - Discussion started: 2 November 2016

Revised: 13 February 2017 - Accepted: 14 February 2017 - Published: 17 March 2017

\begin{abstract}
Schemes used to parameterise ozone dry deposition velocity at the oceanic surface mainly differ in terms of how the dominant term of surface resistance is parameterised. We examine three such schemes and test them in a global climate-chemistry model that incorporates meteorological nudging and monthly-varying reactive-gas emissions. The default scheme invokes the commonly used assumption that the water surface resistance is constant. The other two schemes, named the one-layer and two-layer reactivity schemes, include the simultaneous influence on the water surface resistance of ozone solubility in water, waterside molecular diffusion and turbulent transfer, and a firstorder chemical reaction of ozone with dissolved iodide. Unlike the one-layer scheme, the two-layer scheme can indirectly control the degree of interaction between chemical reaction and turbulent transfer through the specification of a surface reactive layer thickness. A comparison is made of the modelled deposition velocity dependencies on sea surface temperature (SST) and wind speed with recently reported cruise-based observations. The default scheme overestimates the observed deposition velocities by a factor of 2-4 when the chemical reaction is slow (e.g. under colder SSTs in the Southern Ocean). The default scheme has almost no temperature, wind speed, or latitudinal variations in contrast with the observations. The one-layer scheme provides noticeably better variations, but it overestimates deposition velocity by a factor of 2-3 due to an enhancement of the interaction between chemical reaction and turbulent transfer. The two-layer scheme with a surface reactive layer thickness specification of $2.5 \mu \mathrm{m}$, which is approximately equal to the reaction-diffusive length scale of the ozone-iodide reaction, is able to simulate the field measurements most closely with respect to absolute values as well as SST and wind-speed de-
\end{abstract}

pendence. The annual global oceanic deposition of ozone determined using this scheme is approximately half of the original oceanic deposition obtained using the default scheme, and it corresponds to a $10 \%$ decrease in the original estimate of the total global ozone deposition. The previously reported modelled estimate of oceanic deposition is roughly one-third of total deposition and with this new parameterisation it is reduced to $12 \%$ of the modelled total global ozone deposition. Deposition parameterisation influences the predicted atmospheric ozone mixing ratios, especially in the Southern Hemisphere. For the latitudes $45-70^{\circ} \mathrm{S}$, the two-layer scheme improves the prediction of ozone observed at an altitude of $1 \mathrm{~km}$ by $7 \%$ and that within the altitude range $1-6 \mathrm{~km}$ by $5 \%$ compared to the default scheme.

\section{Introduction}

Ozone $\left(\mathrm{O}_{3}\right)$ is not emitted directly into the atmosphere but is formed in both the stratosphere and troposphere by photochemical reactions involving natural and anthropogenic precursor species. Ozone is an oxidant as well as a precursor to the formation of hydroxyl and hydroperoxyl radicals that play a critical role in the chemical cycles of many trace gases in the troposphere. The lifetime of ozone in the troposphere is relatively short, being about 22 days, compared to long-lived and globally well-mixed greenhouse gases such as carbon dioxide $\left(\mathrm{CO}_{2}\right)$. Ozone acts as a greenhouse gas, and adversely impacts human health and plant productivity (Monks et al., 2015). As a greenhouse gas, ozone has the third largest global warming effect after $\mathrm{CO}_{2}$ and methane $\left(\mathrm{CH}_{4}\right)$, and thus plays an important role in the Earth's climate system. The tropospheric ozone burden is estimated to have 
increased by about $40 \%$ since preindustrial times as a result of increases in the emissions of ozone precursors (Young et al., 2013). According to the Fifth Assessment Report (AR5) of the United Nations Intergovernmental Panel on Climate Change (IPCC), the anthropogenic component of the radiative forcing due to ozone is estimated to be $0.35 \pm 0.2 \mathrm{~W} \mathrm{~m}^{-2}$, of which $0.40 \pm 0.2 \mathrm{~W} \mathrm{~m}^{-2}$ is the tropospheric ozone contribution and $-0.05 \pm 0.1 \mathrm{~W} \mathrm{~m}^{-2}$ is the stratospheric contribution. Ozone represents about $15 \%$ of the total anthropogenic radiative forcing (including aerosols) estimated for the year 2011 (IPCC, 2013, AR5, Chapter 8, Anthropogenic and Natural Radiative Forcing).

Aspects of ozone have been investigated in numerous air quality and climate-related studies, including its sources and sinks (e.g. Vingarzan, 2004; Wild, 2007; Stevenson et al., 2006, 2013; Young et al., 2013; Monks et al., 2015). In the troposphere, the ozone budget is determined by transport from the stratosphere, deposition at the Earth's surface, and chemical production and loss. Dry deposition is an important sink of ozone (Galbally and Roy, 1980), which influences near-surface concentration of ozone as well as its lifetime and long-range transport. The "present-day" (about the year 2000) total global dry deposition of ozone estimated by the Atmospheric Chemistry and Climate Model Intercomparison Project (ACCMIP) is of the order of $1094 \pm 264 \mathrm{Tg} \mathrm{yr}^{-1}$, which is almost double the flux of ozone from the stratosphere to the troposphere $\left(477 \pm 96 \mathrm{Tg} \mathrm{yr}^{-1}\right)$ (IPCC, 2013, AR5, Chapter 8, Anthropogenic and Natural Radiative Forcing, Table 8.1, p. 672; Young et al., 2013). Although the average dry deposition velocity to the ocean is smaller than that to terrestrial surfaces, the larger coverage of the Earth's surface by the oceans leads to considerable dry deposition to water - previous modelling studies estimate that about one-third of total ozone deposition is to water (Ganzeveld et al., 2009; Hardacre et al., 2015). Based on results from a multi-model analysis, Hardacre et al. (2015) observed that ozone deposition to the water surface has the largest uncertainty compared to other surface types. The deposition process needs to be properly accounted for when modelling ozone chemistry in the atmosphere, irrespective of whether the application is related to air quality or climate chemistry.

Similar to the land surface, the commonly used parameterisation for dry deposition of gases to the ocean surface is to express deposition velocity $\left(v_{\mathrm{d}}\right)$, which is the flux of the gas to the surface divided by its concentration in air near the surface, as the linear sum of three resistances (Wesely, 1989):

$v_{\mathrm{d}}=\frac{1}{r_{\mathrm{a}}+r_{\mathrm{b}}+r_{\mathrm{c}}}$,

where $r_{\mathrm{a}}, r_{\mathrm{b}}$, and $r_{\mathrm{c}}$ are the resistances exerted on the transfer process in three successive top-to-bottom layers: the aerodynamic resistance $r_{\mathrm{a}}$ is the resistance to mixing by turbulent transport in the atmospheric surface layer, the atmospheric viscous (or quasi-laminar) sublayer resistance $r_{\mathrm{b}}$ is the resistance to movement across the thin layer $(0.1-1 \mathrm{~mm})$ of air that is in direct contact with the surface and not moving with the mean flow of the wind, and the surface resistance $r_{\mathrm{c}}$ is the resistance to uptake by the underlying surface that can be controlled by physical, chemical, and/or biological processes depending on the surface type and species of interest.

For ozone deposition to oceanic surfaces, $r_{\mathrm{c}}$ is the dominant resistance and several approaches have been proposed to calculate it. A common approach is to use a constant value, normally $r_{\mathrm{c}}=2000 \mathrm{~s} \mathrm{~m}^{-1}$, based on Wesely's (1989) deposition parameterisation. Several global chemical transport models use this approach by default, for example, MATCHMPIC (von Kuhlmann et al., 2003), MESSy (Kerkweg et al., 2006), MOZART-4 (Emmons et al., 2010), CAM-chem (Lamarque et al., 2012), GEOS-Chem (Mao et al., 2013), and UKCA (Abraham et al., 2012).

While a constant $r_{\mathrm{c}}$ may be a good first-order estimate of global and long-term average oceanic dry deposition, it does not include any spatial and temporal dependencies of the surface uptake process on any oceanic physical, chemical, or biological properties or processes.

The surface ocean acts as a gateway for molecules to enter the atmosphere or ocean medium and contains complex chemical reactions of inorganic components and dissolved organic matter. Some of these reactions are important sources or sinks of climatically active trace gases. For example, ozone is known to react with a number of dissolved chemical compounds present in the seawater, with the reaction with dissolved iodide being by far the fastest one (Garland et al., 1980; Chang et al., 2004), which needs to be considered. Apart from providing more accurate ozone predictions, a proper treatment of deposition is also important from the point of view of better accounting for feedback cycles; for example, the ozone reaction with iodide in the seawater produces volatile iodine compounds, which may then pass into the atmosphere and participate in catalytic ozone destruction cycles in the marine atmosphere (Carpenter et al., 2013).

For the purpose of clarity we describe the layers of the ocean from the surface down as follows. The top $1 \mu \mathrm{m}-1 \mathrm{~mm}$ of the sea surface is termed the sea surface microlayer (SSM) (Carpenter et al., 2015). The physical and chemical properties of the SSM can be different to those of the bulk water. The SSM may consist of various sublayers or scales depending on the physical or chemical properties being considered. The upper part of the SSM is a region where turbulent mixing is drastically reduced and molecular diffusion dominates, resulting in strong gradients in gas concentrations and other properties. A reaction-diffusion length scale can be defined as $(D / a)^{1 / 2}$ (Carpenter et al., 2013), where $D$ is the molecular diffusivity $\left(\mathrm{m}^{2} \mathrm{~s}^{-1}\right)$ and $a$ is the reaction rate constant $\left(\mathrm{s}^{-1}\right.$ ), and it is typically $3 \mu \mathrm{m}$ (at $\sim 25^{\circ} \mathrm{C}$ ) for the ozoneiodide reaction in seawater. A molecular (or diffusive) sublayer can be defined as the region where ozone molecular diffusivity is greater than turbulent transfer, and is typically $50 \mu \mathrm{m}$ thick. A viscous (or quasi-laminar) sublayer is where viscous processes effectively dissipate the turbulent energy 
and is of the order of $1 \mathrm{~mm}$ (Fairall et al., 2000). In the surface turbulent layer $(\sim 10-50 \mathrm{~m})$ below the viscous sublayer, turbulent processes dominate.

\section{Mechanistic approaches to determining $r_{\mathrm{c}}$}

Most early studies on ozone deposition to seawater explored its dependence on dynamical factors related to turbulent transfer without considering any chemical reaction (e.g. Galbally and Roy, 1980). Other studies have considered molecular diffusion coupled with chemical reactions (e.g. with iodide) in the seawater without including any effects of turbulent transfer (e.g. Garland et al., 1980). Using the assumption of Wanninkhof (1992) that the enhancement of deposition due to chemical processes was additive to the turbulent transfer in water, Chang et al. (2004) formulated $1 / r_{\mathrm{c}}$ as a linear sum of two independent terms with the correct asymptotic behaviours: the first term representing the influence of molecular diffusion coupled with chemical reaction (Garland et al., 1980) and the second term representing the influence of wind-induced turbulent transfer coupled with a chemical enhancement factor (Liss and Merlivat, 1986).

More recently, by solving a simplified form of the budget equation for mass conservation that includes turbulent and molecular transport and a chemical reaction term, Fairall et al. (2007) derived two formulations for $r_{\mathrm{c}}$ that are able to account for the simultaneous effects of oceanic physical and chemical processes (i.e. ozone solubility, molecular diffusion, turbulent transfer, and chemical reaction). Their approach signifies a development based on fundamental conservation laws.

Some of the processes affecting deposition act in opposite directions and some are interlinked (e.g. ozone solubility in water and reaction rate coefficient are a function of sea surface temperature, SST, but in the opposite way). Thus, a proper way to evaluate a mechanistic deposition scheme against field measurements is to couple it to an atmospheric composition model and then analyse the response of the full coupled system that represents the conditions of the measurements. Ganzeveld et al. (2009) explored the response of a free-running global climate-chemistry model to the choice of a constant $r_{\mathrm{c}}$ and the one-layer reactivity parameterisation derived by Fairall et al. (2007) (described later in Sect. 5) and compared the modelled ozone deposition velocity with observations reported in the literature. Since then there have been new deposition velocity data reported by Helmig et al. (2012), which together with the inclusion of atmospheric model features such as meteorological nudging, could lead to potential improvements in parameterisation of deposition velocity.

Helmig et al. (2012) presented the first shipborne openocean ozone flux measurements and at the same time the most extensive set of these measurements (1700 hourly periods of observations), probably surpassing all previous data.
The measurements covered the Gulf of Mexico, the southern and northern Atlantic, the Southern Ocean, and the eastern Pacific Ocean. These experiments gave medians of the oceanic ozone deposition velocity $\left(v_{\mathrm{d}}\right)$ from the five cruises of $0.009-0.034 \mathrm{~cm} \mathrm{~s}^{-1}$. The measurements cover the range of $45^{\circ} \mathrm{N}-50^{\circ} \mathrm{S}$ and show little wind-speed dependence but a marked sea surface temperature dependence. This dataset provides a unique opportunity to both test oceanic ozone deposition schemes and re-evaluate the ozone deposition rate to the world's oceans.

The aims of this paper are (a) to examine schemes of ozone dry deposition to the ocean involving the default constant $r_{\mathrm{c}}$ assumption, the one-layer reactivity model suggested by Fairall et al. (2007), and a development of their two-layer reactivity model, within a global climate-chemistry model, ACCESS-UKCA, which incorporates meteorological nudging and monthly-varying reactive-gas emissions, and then compare the results with the ozone deposition data of Helmig et al. (2012). This comparing enables selection of an improved deposition formulation. Then (b) using the best fitting scheme, we re-evaluate the rate of ozone deposition over the ocean and for the combined ocean-land system, and finally (c) with the best fitting scheme, we examine its influence on the comparison of modelled ozone compared with global ozone profile observations covering the troposphere.

\section{ACCESS-UKCA chemistry-climate model}

The Australian Community Climate and Earth System Simulator (ACCESS, see Bi et al., 2013) has been developed for both climate and numerical weather prediction purposes. The physical atmosphere component of ACCESS is the UK Met Office's Unified Model (MetUM). The UK Chemistry and Aerosol (UKCA, http://www.ukca.ac.uk, described below) atmospheric composition module (at UM vn8.4; see Abraham et al., 2012) is part of ACCESS, and the resulting model is referred to here as ACCESS-UKCA.

Several different chemical schemes are available within UKCA. The configuration used here (at UM vn8.4) combines the tropospheric chemistry scheme described by O'Connor et al. (2014) and the stratospheric chemistry as described by Morgenstern et al. (2009). The resulting chemistry configuration is known as Chemistry of the Stratosphere and Troposphere (CheST). The tropospheric chemistry scheme accounts for $\mathrm{O}_{x}, \mathrm{HO}_{x}, \mathrm{NO}_{x}, \mathrm{CH}_{4}$, and other volatile organic carbon species (e.g. isoprene). The stratospheric chemistry scheme includes chlorine and bromine chemistry (for ozonedepleting substances, ODS) and heterogeneous polar stratospheric cloud chemistry suitable for simulating stratospheric ozone. The Fast-JX photolysis scheme (Neu et al., 2007) is used in the CheST configuration and is applicable both in the troposphere and stratosphere. For aerosols, the size-resolved aerosol microphysics scheme GLOMAP-mode, which includes sulfur chemistry, is used (Mann et al., 2010). The total 
number of reactions is 306 across 86 species. Interactive gasphase dry and wet deposition processes are included. The chemical reactions together with relevant deposition rates are solved within the ASAD (A Self-contained Atmospheric chemistry coDe) framework.

UKCA is coupled to a radiation scheme (via $\mathrm{O}_{3}, \mathrm{CH}_{4}$, $\mathrm{N}_{2} \mathrm{O}$, and aerosol direct and indirect effects). Changes in atmospheric composition are thus allowed to impact model physics, allowing the representation of feedbacks from chemical composition to atmospheric dynamics when operating in a free-running (un-nudged) climate configuration. ACCESS also has a coupled ocean model, but the present configuration used an atmosphere-only set-up forced by observed sea surface temperature and sea ice fields.

The atmospheric model domain is global, with 85 levels extending from the surface to approximately $85 \mathrm{~km}$, and the horizontal resolution was $1.875^{\circ}$ in longitude and $1.25^{\circ}$ in latitude (the so-called N96L85 configuration).

In order for a free-running global climate model to realistically reproduce the state of the atmosphere, especially for process studies at short timescales and subsequent comparison with measured data, meteorological nudging is often used. Nudging is a simple data assimilation technique that uses meteorological reanalysis data to relax dynamical variables of a model towards the observed state of the atmosphere at a given time, thus minimising meteorology as a source of uncertainty in the modelled fields. The variables, horizontal wind components and potential temperature in the free troposphere, are nudged by using the ERA-Interim reanalyses on pressure levels (Telford et al., 2008; Uhe and Thatcher, 2015).

A global monthly-varying emissions database for reactive gases and aerosols that includes both anthropogenic and natural components was compiled for ACCESS-UKCA and is described in detail by Woodhouse et al. (2015), with the exception that here we used GFED4s (including small fires) biomass burning emission data instead of the original ACCMIP database; the former includes interannual variability. For methane, nitrous oxide, and ozone-depleting substances, concentrations are prescribed instead of emissions.

The model has nine surface types (namely broad-leaf trees, needle-leaf trees, $\mathrm{C} 3$ and $\mathrm{C} 4$ grass, shrub, urban, water, bare soil, and land ice) and for a particular grid box the three resistances are calculated for each surface type and a corresponding deposition velocity is then computed. A first-order loss rate is calculated as the deposition velocity divided by the height of the atmospheric boundary layer (ABL), and this loss rate is applied at each model level contained within the ABL. A grid-box mean loss rate at each model level within the ABL is then obtained by weighting the individual loss rates with the fractions of the surface types present in the grid box. The mean loss rate is used in the species mass conservation equation. Currently there is only one water surface type in the model; thus, the same deposition scheme is used for both seawater and freshwater. In our analysis for the oceanic deposition, we do not consider any coastal grid cells and only consider those grid cells that are $100 \%$ covered by the water surface type.

\subsection{Current scheme for ozone dry deposition to water}

In ACCESS-UKCA, the aerodynamic resistance $r_{\mathrm{a}}$ is a function of sea surface roughness, wind speed, and atmospheric stability and is determined as

$r_{\mathrm{a}}=\frac{\ln \left(z_{\mathrm{r}} / z_{0}\right)-\psi}{\kappa u_{*}}$,

where $u_{*}$ is the air friction velocity, $z_{\mathrm{r}}$ is a reference height $(=50 \mathrm{~m}), \kappa$ is the von Kármán constant $(=0.4)$, and $\psi$ is a stability correction function. The aerodynamic roughness length $z_{0}$ for the sea surface is parameterised as the sum of viscous and gravity wave parts (Smith, 1988):

$z_{0}=\frac{0.11 v_{\mathrm{a}}}{u_{*}}+\frac{a_{\mathrm{c}} u_{*}^{2}}{g}$,

where the kinematic viscosity of air $v_{\mathrm{a}}$ is a function of surface temperature and air density, $a_{\mathrm{c}}$ is a Charnock coefficient (= 0.016 ), and $g$ is the acceleration due to gravity.

The resistance $r_{\mathrm{b}}$ is related to molecular properties of the gas as well as atmospheric turbulence through the following relationship (Hicks et al., 1987):

$r_{\mathrm{b}}=\left(\frac{S c}{P r}\right)^{2 / 3} \frac{1}{\kappa u_{*}}$,

where $S c$ is the Schmidt number defined as the ratio of the kinematic viscosity of air to molecular diffusivity of the gas species in air and $P r$ is the Prandtl number of air (i.e. the ratio of momentum diffusivity to thermal diffusivity $\approx 0.72$ ). The molecular diffusivity of ozone in air is taken as $1.4 \times$ $10^{-5} \mathrm{~m}^{2} \mathrm{~s}^{-1}$.

The present version of ACCESS-UKCA uses $r_{\mathrm{c}}=$ $2200 \mathrm{~s} \mathrm{~m}^{-1}$, which yields a ceiling value for $v_{\mathrm{d}}$ of $1 / r_{\mathrm{c}}=$ $0.0455 \mathrm{~cm} \mathrm{~s}^{-1}$. This will be the first (or default) model specification for ozone deposition in our study.

\section{Ozone loss in seawater}

Garland et al. (1980) introduced the idea that ozone loss in the ocean was dominated by its reaction with dissolved iodide ions $\left(\mathrm{O}_{3}+\mathrm{I}^{-} \rightarrow\right.$ products $)$ within the seawater. This bimolecular reaction is considered pseudo-first-order in several models of ozone loss in seawater because only a very small proportion of iodide is used and its concentration remains almost constant. The first-order rate coefficient $a\left(\mathrm{~s}^{-1}\right)$ is equal to the pertinent second-order rate coefficient $(k)$ times the iodide concentration $\left[\mathrm{I}^{-}\right]$, i.e.

$a=k \cdot\left[\mathrm{I}^{-}\right]$, 
where $\left[\mathrm{I}^{-}\right]$is in mole per litre (or molar, M) and $k$ is in $\mathrm{M}^{-1} \mathrm{~s}^{-1}$. If there are other first-order reactions, then the total reaction rate can be determined as $a=\sum_{i} k_{i} C_{i}$, where $k_{i}$ and $C_{i}$ are the first-order rate coefficient and concentration respectively of the $i$ th species.

Equation (5) represents the integrated reactivity given for the bulk reaction $\left(\mathrm{O}_{3}+\mathrm{I}^{-} \rightarrow\right.$ products $)$ and is used in this model to calculate the ozone removal by reaction with iodide. However, it is noted that the chemistry of ozone reaction with iodide in aqueous solution is complex (e.g. Sakamoto et al., 2009). There can also be complicating factors, including reactions of ozone with other halogens in seawater (Sarwar et al., 2015), the modification of bulk properties of seawater in the surface microlayer, and the presence of organic compounds in seawater including those preferentially concentrated in the sea surface microlayer (Carpenter et al., 2015). These are not addressed here.

The second-order rate coefficient $(k)$ in Eq. (5) is derived from the data of Magi et al. (1997) (see Sect. "Parameterisation of input quantities").

\section{An alternative scheme for $r_{\mathrm{c}}$ in ACCESS-UKCA}

Atmospheric ozone in passing into the ocean is transferred by molecular diffusion through the sea surface microlayer (including viscous sublayer) and then by turbulent processes in the surface turbulent layer. At the same time, ozone can be lost by chemical reaction.

Considering current knowledge, assuming that iodide does provide a major sink for ozone in the ocean, the resistance to ozone deposition by the ocean surface will be an unknown function of a number of known variables:

$r_{\mathrm{c}}=f\left(\left[\mathrm{I}^{-}\right], k, T_{\mathrm{s}}, \alpha, D, u_{* \mathrm{w}}\right)$,

where $\alpha$ is the dimensionless solubility of ozone in water (which is the ratio of the aqueous-phase ozone concentration to its gas-phase concentration and is related to Henry's law coefficient), $T_{\mathrm{S}}$ is the water temperature, $D$ is the molecular diffusivity of ozone in seawater, and $u_{* \mathrm{w}}$ is the waterside friction velocity. $r_{\mathrm{c}}$ is expressed as (Liss and Merlivat, 1986)

$r_{\mathrm{c}}=\frac{1}{\alpha v_{\mathrm{dw}}}$,

where $v_{\mathrm{dw}}$ is the waterside deposition velocity of ozone. $u_{* \mathrm{w}}$ is calculated as $u_{* \mathrm{w}}=\left(\rho_{\mathrm{a}} / \rho_{\mathrm{w}}\right)^{1 / 2} u_{*}$ by assuming that the atmospheric surface stress is equal to the waterside surface stress, where $\rho_{\mathrm{a}}$ is the air density and $\rho_{\mathrm{W}}$ is the water density.

Applying horizontal homogeneity and stationarity to the fundamental equation for the conservation of mass of a reactive and diffusive substance in water yields the following equation in the vertical dimension ( $z$, i.e. depth from the water surface) (Fairall et al., 2007):

$\frac{\partial}{\partial z}\left[\left(D+K_{\mathrm{t}}\right) \frac{\partial C}{\partial z}\right]-a C=0$, where $C$ is concentration and $K_{\mathrm{t}}$ is the turbulent diffusivity. By assuming $K_{\mathrm{t}}=\kappa u_{* \mathrm{w}} z$, Fairall et al. (2007) solved Eq. (8) to obtain

$v_{\mathrm{dw}}=(a D)^{1 / 2}\left[\frac{K_{1}\left(\xi_{0}\right)}{K_{0}\left(\xi_{0}\right)}\right]$,

where $K_{n}(\xi)$ is the modified Bessel function of the second kind of order $n, \xi_{0}=b(a D)^{1 / 2}$ and $b=2 /\left(\kappa u_{* \mathrm{w}}\right)$. Equation (9) explicitly includes the role of waterside molecular diffusion, turbulent transfer, and first-order chemical reaction. In the limit of fast reaction or negligible turbulence, it reduces to

$v_{\mathrm{dw}}=(a D)^{1 / 2}$,

which is the form proposed by Garland et al. (1980). The scheme above forms part of the COAREG group of gas transfer algorithms (Fairall et al., 2011).

There are four controlling parameters involved in the scheme above for $r_{\mathrm{c}}$ (Eqs. 7 and 9): ozone solubility, molecular diffusion, turbulent transfer, and chemical reaction. Deposition velocity increases as these parameters attain larger values. This scheme is termed the one-layer reactivity scheme due to the assumption of uniform reactivity $(a)$ through the ocean depth. We incorporated the scheme above for $r_{\mathrm{c}}$ in ACCESS-UKCA. This will be the second model specification for ozone deposition.

\section{Parameterisation of input quantities}

The second-order rate coefficient $k\left(\mathrm{M}^{-1} \mathrm{~s}^{-1}\right)$ is derived by fitting an Arrhenius-type expression for $k$ as a function of water temperature $T_{\mathrm{S}}(\mathrm{K})$ to the data of Magi et al. (1997):

$k=\exp \left(\frac{-8772.2}{T_{\mathrm{S}}}+51.5\right)$.

Ganzeveld et al. (2009) used oceanic surface nitrate concentration as a proxy for iodide concentration. Chance et al. (2014) compiled available measurements of sea surface iodide, which show the highest iodide concentrations in tropical waters. They examined statistical relationships between iodide and parameters such as SST, nitrate, salinity, chlorophyll- $a$, and mixed layer depth and found that SST $\left(T_{\mathrm{s}}\right)$ was the strongest predictor of iodide, followed by latitude. MacDonald et al. (2014) used data from several cruises in the Atlantic and Pacific oceans covering the latitudes $50^{\circ} \mathrm{S}-$ $50^{\circ} \mathrm{N}$ to derive the following parameterisation for iodide concentration:

$\left[\mathrm{I}^{-}\right](\mathrm{nM})=1.46 \times 10^{15} \exp \left(\frac{-9134}{T_{\mathrm{S}}}\right)$.

In their study on iodine's impact on tropospheric oxidants, Sherwen et al. (2016) found that the MacDonald et al. (2014) parameterisation provided better results than the iodide-SST regression parameterisation derived by Chance et al. (2014). 
We use Eq. (12) in our ACCESS-UKCA modelling, but a sensitivity to the iodide parameterisation derived by Chance et al. (2014) will also be explored later. Based on Eq. (12), the concentrations of iodide lie in the range of 6-160 nM, and the reaction timescale $a$ lies in the range of $2-1350 \mathrm{~s}^{-1}$ for the experimental conditions modelled. Iodide concentrations are highest in warm tropical waters and lowest in cool waters at higher latitudes.

The dimensionless solubility of ozone in water $\alpha$ decreases with water temperature and is parameterised as (Morris, 1988)

$\log _{10}(\alpha)=-0.25-0.013\left(T_{\mathrm{s}}-273.16\right)$.

The molecular diffusivity $D\left(\mathrm{~m}^{2} \mathrm{~s}^{-1}\right)$ of ozone in water is expressed as (Johnson and Davis, 1996)

$D=1.1 \times 10^{-6} \exp \left(\frac{-1896}{T_{\mathrm{s}}}\right)$.

We ran ACCESS-UKCA with both the default scheme and the one-layer reactivity scheme above. The modified Bessel functions were determined using the numerical algorithms given by Press et al. (1992). The values of $(a D)^{1 / 2}$ (see Eq. 10) increase by a factor of 30 from high-latitude cold waters to tropical warm waters in the model calculations.

\section{Comparison of observed and modelled ozone dry deposition velocity to the ocean surface}

Helmig et al. (2012) reported the magnitude and variability of ozone deposition velocity measured over the open ocean from a ship-based eddy-covariance ozone flux system during 2006-2008. The experiments were conducted on five cruises, namely (1) TexAQS06 (7 July-12 September 2006), (2) STRATUS06 (9-27 October 2006), (3) GOMECC07 (11 July-4 August 2007), (4) GasEx08 (29 February11 April 2008), and (5) AMMA08 (27 April-18 May 2008). The respective areas covered were (1) north-western Gulf of Mexico, (2) the persistent stratus cloud region off Chile in the eastern Pacific Ocean, (3) the Gulf of Mexico and the US east coast, (4) the Southern Ocean, and (5) the southern and northern Atlantic Ocean. Helmig et al. (2012) present a map of cruise tracks together with bin-averaged deposition velocity data as a function of SST and wind speed for each of the five cruises. Information on the actual timings and locations of the observations along the cruise tracks was not available.

Helmig et al. (2012) plotted the observed $v_{\mathrm{d}}$ values against SST, but in order to compare the data with the $v_{\mathrm{d}}$ values obtained from the offline one-layer reactivity scheme of Fairall et al. (2007), they removed the wind-speed dependence from their data. This resulted in an idealised testing of the model scheme, omitting the joint influences of SST and wind speed that occur at the specific field locations. In the present case, this scheme has been coupled to an atmospheric chemistry model in which all input parameters are supplied and act simultaneously in determining $v_{\mathrm{d}}$ for the specific field program locations and durations so that the modelled value and data can be compared directly. We obtained the same $v_{\mathrm{d}}-$ SST data but without the wind-speed dependence removed (L. Bariteau, personal communication, 2016) for a consistent comparison with our model results (although there is not a large difference between the data with and without the windspeed dependence).

The ACCESS-UKCA model was run from January 2005 until the end of 2008. The model output was used for 2006 onwards and consists of monthly averaged values of deposition parameters at each grid point. The simulation months and years were matched with the experimental periods. The model output was extracted at a series of grid-point locations with almost uniform spacings along the tracks of the experimental cruises above, and the modelled values at these points were used for comparison with the measurements. It is noted that the deposition velocity data and modelled values cannot be matched exactly in terms of time and location. The cruise data are averaged with respect to SST or windspeed bins over a given experimental period. They may vary in both space and time (but information on any such variation was not available). Conversely, the model values are monthly averages extracted along the cruise tracks, with the model months matched to the months corresponding to the experimental periods, which means the binning is dominated by spatial changes. This matching difference is not expected to pose a significant problem for comparison purposes because the deposition velocity variations are mainly examined in terms of SST, which is not expected to vary greatly with time at a given location for a typical experimental period under consideration, and the ozone concentration in marine air has only a minor diurnal variation (Galbally et al., 2000). (Note, however, that in contrast to oceanic deposition, land-based deposition over vegetated surfaces typically has a strong diurnal dependence as a result of the strong diurnal variations in ozone concentrations and in the stomatal uptake.)

The $v_{\mathrm{d}}-\mathrm{SST}$ plot in Fig. 1 shows that although there are large fluctuations in the data from the various field experiments, a trend of $v_{\mathrm{d}}$ increasing with SST is apparent. The lowest deposition velocities are observed in the Southern Ocean (GasEx08) and the largest are observed from the TexAQS06 experiment in the north-western Gulf of Mexico. An interpretation of this observed variation is that despite the stronger wind and wave conditions normally present at Southern Ocean latitudes and the higher ozone solubility due to cooler temperatures there, the deposition velocities are lower because of the lower iodide concentrations at such temperatures, which results in a slower ozone loss rate. Conversely, the observed deposition velocities in the northwestern Gulf of Mexico are larger due to warmer waters and higher iodide concentrations, leading to faster ozone loss rate despite relatively weak winds and lower ozone solubility there. 


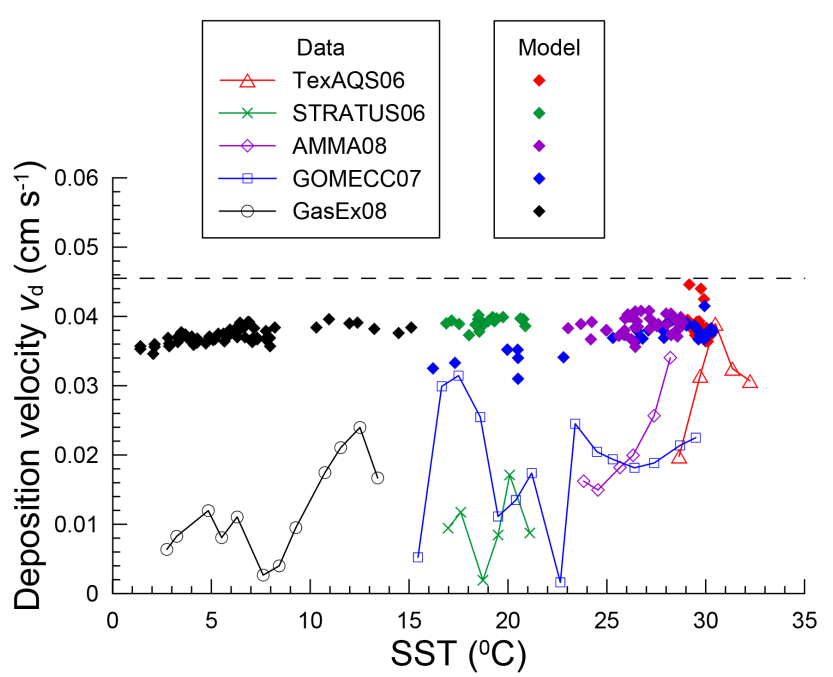

Figure 1. Ozone dry deposition velocity $\left(v_{\mathrm{d}}\right)$ as a function of sea surface temperature (SST) from five field experiments (Helmig et al., 2012; L. Bariteau, personal communication, 2016) and the corresponding values obtained from the ACCESS-UKCA model using the default parameterisation for ozone deposition to the ocean involving a constant surface resistance of $r_{\mathrm{c}}=2200 \mathrm{~s} \mathrm{~m}^{-1}$. The dashed line is the ceiling value corresponding to $1 / r_{\mathrm{c}}=$ $100 / 2200=0.0455 \mathrm{~cm} \mathrm{~s}^{-1}$.

Figure 1 shows the ACCESS-UKCA predictions obtained using the default (i.e. constant $r_{\mathrm{c}}$ ) deposition scheme for the five experiments (diamonds use the same colours as the data). The range of SSTs from the model for different experiments is in agreement with the measurements, with the lowest values predicted for GasEx08 and the highest for TexAQS06 and GOMECC 07 . However, the modelled $v_{\mathrm{d}}$ is virtually constant at $0.038 \mathrm{~cm} \mathrm{~s}^{-1}$, and the observed variation is progressively overestimated by a factor of 2-4 as water temperatures get cooler. This model behaviour with SST is a consequence of the model using a constant value for the dominant resistance $r_{\mathrm{c}}$, resulting in a near-constant $v_{\mathrm{d}}$ with a ceiling value of $1 / r_{\mathrm{c}}=100 / 2200=0.0455 \mathrm{~cm} \mathrm{~s}^{-1}$. The difference between the ceiling value and a modelled value corresponds to the contribution made by the airside resistances $\left(r_{\mathrm{a}}\right.$ and $r_{\mathrm{b}}$ in Eq. 1) to lower the deposition velocity. The comparison in Fig. 1 demonstrates that the constant $r_{\mathrm{c}}$ assumption is not satisfactory with respect to both its absolute value and its lack of variation with SST.

Figure 2a shows the same $v_{\mathrm{d}}-\mathrm{SST}$ plot as in Fig. 1 but with the modelled values obtained using the one-layer reactivity scheme. Even though the molecular diffusion controlled deposition component $(a D)^{1 / 2}$ increases by a factor of 30 from high-latitude cold waters to tropical warm waters, a variation to that extent is not evident in Fig. 2a because turbulent transfer starts to dominate deposition as surface temperatures decrease (this is illustrated in the sensitivity analysis presented later in Sect. 6.1.1). Compared to Fig. 1, the one-layer de-
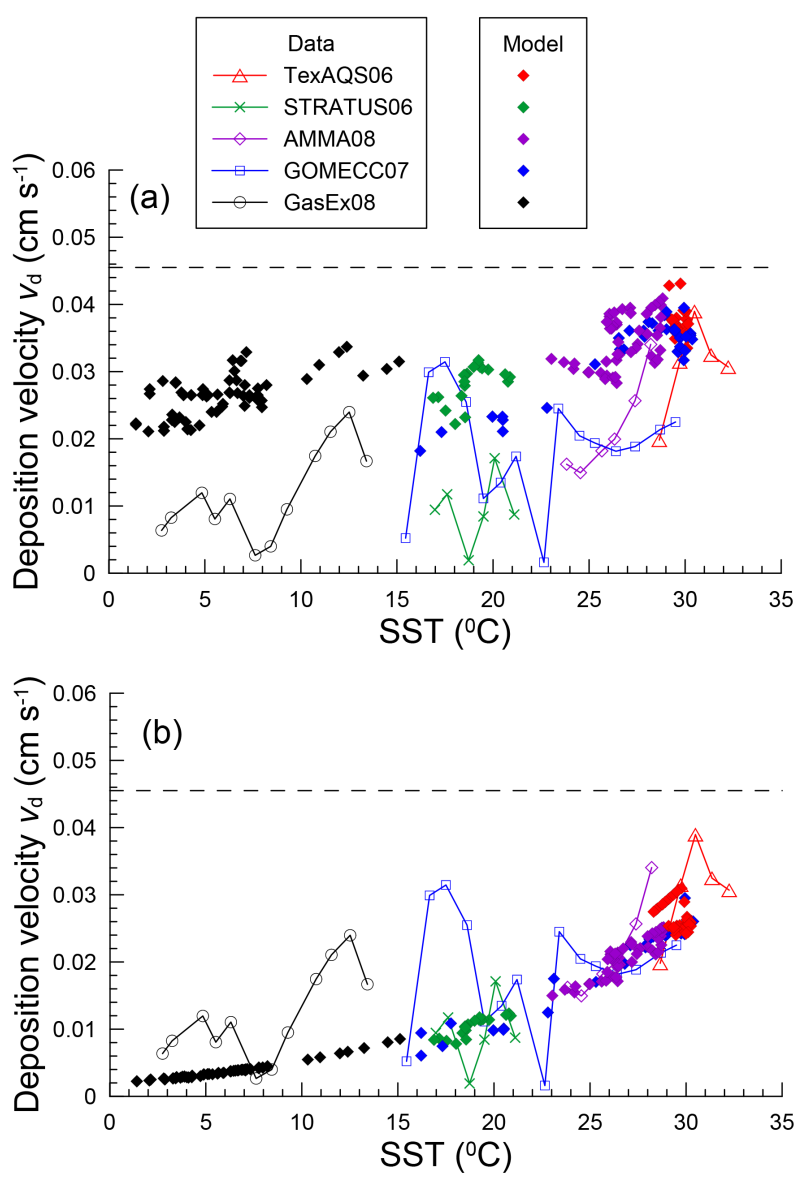

Figure 2. Ozone dry deposition velocity $\left(v_{\mathrm{d}}\right)$ as a function of sea surface temperature (SST) from five field experiments (Helmig et al., 2012; L. Bariteau, personal communication, 2016) and the corresponding values obtained from the ACCESS-UKCA model using (a) the one-layer reactivity scheme for ozone deposition to the ocean and (b) the one-layer reactivity scheme without waterside turbulence.

position scheme is able to noticeably better reproduce the observed trend of $v_{\mathrm{d}}$ increasing with SST and the large observed fluctuations in $v_{\mathrm{d}}$. However, the model still overestimates $v_{\mathrm{d}}$ by a factor of $2-3$, with the difference between model and data getting progressively larger as the water temperatures get cooler. In Fig. 2b we plot the behaviour of the one-layer reactivity scheme with the contribution of waterside turbulence removed. Compared to Fig. 2a, the modelled deposition velocities are lower in magnitude and compare better with the data. However, it is clear that for SSTs lower than about $15^{\circ} \mathrm{C}$, the model without the waterside turbulence underestimates the deposition velocities compared with the measurements because the influence of waterside turbulence becomes important compared to weaker chemical reaction at lower temperatures. Overall, what this comparison suggests is that the influence of waterside turbulence in the one-layer 


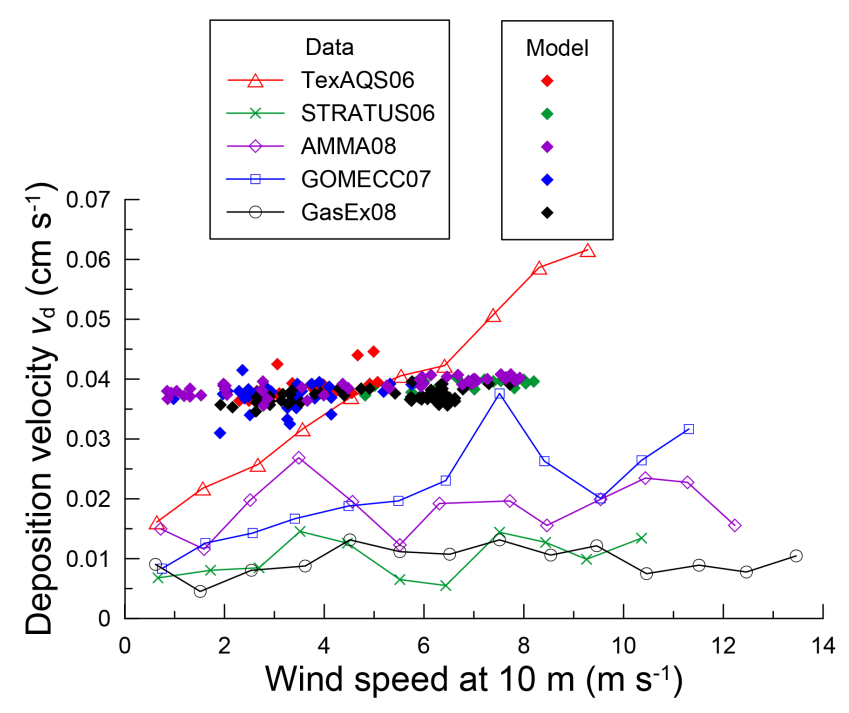

Figure 3. Ozone dry deposition velocity $\left(v_{\mathrm{d}}\right)$ as a function of wind speed at $10 \mathrm{~m}$ height from five field experiments (Helmig et al., 2012) and the corresponding values obtained from the ACCESSUKCA model with the default parameterisation for ozone deposition to the ocean.

reactivity scheme is overestimated, and this point will be discussed later on in the paper.

In Fig. 3, the modelled variation of $v_{\mathrm{d}}$ with wind speed (at $10 \mathrm{~m}$ height) obtained using the default deposition scheme does not agree with the measurements, with the modelled $v_{\mathrm{d}}$ values almost constant as in Fig. 1, whereas the data show an increasing $v_{\mathrm{d}}$ with wind speed for TexAQS06 and to a lesser extent for GOMECC07. For the other three experiments the variation is almost constant, but it is much lower in magnitude than that estimated by the model. It is apparent that the higher-end range of the modelled wind speed is smaller than that of the data, largely because the wind extremes are averaged out in the modelled monthly averages. This is not as much an issue in the earlier comparison involving SST because this parameter does not change as much temporally as wind speed. Hence, in the present case, the $v_{\mathrm{d}}$-wind speed comparison is perhaps not as robust as the $v_{\mathrm{d}}-\mathrm{SST}$ comparison.

Figure 4 compares the measured $v_{\mathrm{d}}$ variations with wind speed against those computed using the one-layer deposition scheme. The model is able to perform somewhat better than that in Fig. 3 for a constant $r_{\mathrm{c}}$, with a hint of the model curves for the five experiments separating out in a manner that is qualitatively consistent with the data.

It is apparent from the comparison above that the one-layer mechanistic scheme given by Eq. (9) is able to yield trends in deposition velocity in the right direction, but the modelled deposition velocities are still overestimated compared to the observed values overall.

The likely reason for the overestimation of deposition velocity by the one-layer reactivity scheme is that it overes-

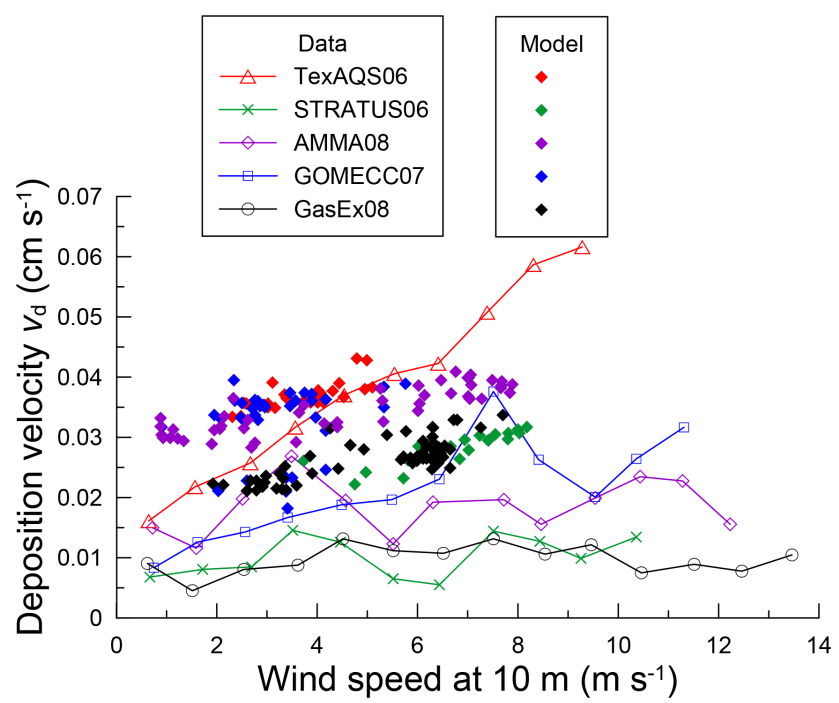

Figure 4. Ozone dry deposition velocity $\left(v_{\mathrm{d}}\right)$ as a function of wind speed at $10 \mathrm{~m}$ height from five field experiments (Helmig et al., 2012) and the corresponding values obtained from the ACCESSUKCA model using the one-layer reactivity scheme for ozone deposition to the ocean.

timates the influence of waterside turbulence and, consequently, its interaction with the chemical reaction as a result of the use of a turbulent diffusivity parameterisation $K_{\mathrm{t}}=\kappa u_{* \mathrm{w}} z_{\mathrm{w}}$ that is linear in $z_{\mathrm{w}}$, the distance (or depth) from the water surface. This parameterisation is valid in the surface layer with fully developed turbulence, but in the small viscous sublayer $\left(z_{\mathrm{w}}<\delta_{u}\right)$ (whose thickness $\delta_{u}=11 v / u_{* \mathrm{w}}$, where $v$ is the kinematic viscosity of seawater) is of the order of $1 \mathrm{~mm}$ under typical conditions, the above $K_{\mathrm{t}}$ parameterisation would overestimate turbulent transfer because it ignores the dissipation of small-scale turbulence by viscosity. This is important because the length scale of the ozoneiodide reaction falls within the viscous sublayer. It is suggested that $K_{\mathrm{t}}$ varies as $z_{\mathrm{w}}^{m+1}$ in the viscous sublayer, where $m=2$ for a smooth surface (Fairall et al., 2000). A form for $K_{\mathrm{t}}$ that is valid for both $z_{\mathrm{W}}<\delta_{u}$ and $z_{\mathrm{W}}>\delta_{u}$, such as $K_{\mathrm{t}}=\kappa u_{* \mathrm{w}} z_{\mathrm{w}} /\left[1+\left(\delta_{u} / z_{\mathrm{w}}\right)^{m}\right]$, may be considered in Eq. (8) but an analytical solution is currently elusive. Based on this more general form for $K_{\mathrm{t}}$, we can determine that for $z_{\mathrm{w}} \ll \delta_{u}$ the form $K_{\mathrm{t}}=\kappa u_{* \mathrm{w}} z_{\mathrm{w}}$ would overestimate $K_{\mathrm{t}}$ by a factor of $\left(\delta_{u} / z_{\mathrm{W}}\right)^{m}$. A consequence of this would be to artificially elevate ozone deposition rates to the ocean, especially in regions where the ozone removal chemistry in the surface layer is slow (i.e. areas with cooler SSTs).

\subsection{Two-layer reactivity scheme - improved formulation}

Fairall et al. (2007) extended the one-layer scheme by considering a two-layer approach in which a thin layer of depth $\delta_{m}$ below the water surface has a high reactivity $(a)$ and the 
region below $\delta_{m}$ has a very small background reactivity $\left(a_{0}\right)$ that is present everywhere, including the first layer (thus, the total reactivity of the first layer is $a+a_{0}$ ). The assumption is that virtually all the chemical reaction takes place within this thin layer, which is roughly identified with the surface microlayer.

At this stage we acknowledge that there is iodide below the surface microlayer and that ozone may transfer into that layer and be rapidly destroyed. Thus, the two-layer scheme has an arbitrary constraint that differs somewhat from nature. We describe this model as a semi-empirical model where the appropriate physical and chemical variables have been included in the model, where the turbulence scheme has limitations already discussed, and whereby an arbitrary condition, the depth of the reactive layer, is imposed. The usefulness of the model depends on two issues: (1) whether the model is able to accurately represent the available ozone seawater deposition data and (2) whether the model formulation is suitable for efficient use within global climate composition models. These will both be addressed.

The expression for the waterside transfer velocity from the two-layer water reactivity model is

$v_{\mathrm{dw}}=\left[\left(a+a_{0}\right) D\right]^{1 / 2}\left[\frac{-A_{1} I_{1}\left(\xi_{0}\right)+B_{1} K_{1}\left(\xi_{0}\right)}{A_{1} I_{0}\left(\xi_{0}\right)+B_{1} K_{0}\left(\xi_{0}\right)}\right]$,

where $I_{n}(\xi)$ is the modified Bessel function of the first kind of order $n, \xi_{0}=b\left[\left(a+a_{0}\right) D\right]^{1 / 2}$ and $b=2 /\left(\kappa u_{*}\right)$. The coefficients $A_{1}$ and $B_{1}$ are determined by imposing three boundary conditions: the total flux at the water surface obtained using the solution of the mass conservation Eq. (8) should be equal to a constant specified value $F_{0}$, the concentration at the interface of the two layers should be continuous, and the molecular and turbulent mixing component of the total flux at the interface of the two layers should be continuous. These boundary conditions lead to the following equations respectively:

$$
\begin{aligned}
& -A_{1} \xi_{0} I_{1}\left(\xi_{0}\right)+B_{1} \xi_{0} K_{1}\left(\xi_{0}\right)=\frac{2 F_{0}}{\kappa u_{*}} \\
& A_{1} I_{0}\left(\xi_{\delta 1}\right)+B_{1} K_{0}\left(\xi_{\delta 1}\right)-B_{2} K_{0}\left(\xi_{\delta 2}\right)=0 \\
& -A_{1} \xi_{\delta 1} I_{1}\left(\xi_{\delta 1}\right)+B_{1} \xi_{\delta 1} K_{1}\left(\xi_{\delta 1}\right)-B_{2} \xi_{\delta 2} K_{1}\left(\xi_{\delta 2}\right)=0
\end{aligned}
$$

where $\quad \xi_{\delta 1}=\left[2 b\left(a+a_{0}\right)\left(\delta_{m}+(b D / 2)\right)\right]^{1 / 2} \quad$ and $\xi_{\delta 2}=\left[2 b a_{0}\left(\delta_{m}+(b D / 2)\right)\right]^{1 / 2}$. Although Fairall et al. (2007) allude to the condition corresponding to Eq. (18), they used a different equation in lieu of Eq. (18) by imposing the condition that the total depletion of concentration caused by diffusion and reaction through the depth of the medium must equal the surface flux $F_{0}$. However, their equation involves integration terms that currently need to be determined numerically, thus increasing the computational time considerably when used in a large-scale atmospheric model such as ours. We found that the results obtained using both the equations are the same. In Eq. (16), $F_{0}$ can be taken as unity because it cancels out in the formula for deposition velocity expressed as flux divided by concentration at the surface.

To solve Eqs. (16)-(18) for the three unknowns $A_{1}, B_{1}$, and $B_{2}$, the expression for $A_{1}$ obtained from Eq. (16) is substituted in Eqs. (17) and (18), and the last two are then solved for $B_{1}$ and $B_{2}$ analytically by inverting the $2 \times 2$ matrix of the coefficients $B_{1}$ and $B_{2}$. $A_{1}$ is obtained by putting the solution for $B_{1}$ back in Eq. (16). The two-layer scheme has not been previously tested with any measurements.

\subsubsection{Sensitivity analysis}

Deposition velocity is sensitive to the value of $\delta_{m}$ in the twolayer scheme. To explore this, we tested this scheme in standalone mode (i.e. outside ACCESS-UKCA). The oceanic component of dry deposition velocity, i.e. $\alpha v_{\mathrm{dw}}\left(=1 / r_{\mathrm{c}}\right)$ was calculated using Eq. (15) as a function of sea surface temperature and reactivity for a range of $\delta_{m}$ values for a typical value of the waterside friction velocity $\left(u_{* \mathrm{w}}\right)$ of $0.01 \mathrm{~m} \mathrm{~s}^{-1}$ (which is equivalent to the airside $u_{*} \approx 0.3 \mathrm{~m} \mathrm{~s}^{-1}$ ). The parameterisations of $\left[\mathrm{I}^{-}\right], k, D$, and $\alpha$ specified earlier and $a_{0}=10^{-4} \mathrm{~s}^{-1}$ (Fairall et al., 2007) were used. The results are presented in Fig. 5a and b, along with the curves obtained using the one-layer scheme with and without waterside turbulence (i.e. $K_{\mathrm{t}}=0$ ). These results show that

1. the variation of $\alpha v_{\mathrm{dw}}$ with $\mathrm{SST}$ is very similar to that with reactivity (the latter on a logarithmic scale);

2. the thicker the $\delta_{m}$, the higher the deposition velocity, and that for a sufficiently large $\delta_{m}$ of about $1 \mathrm{~mm}$ the two-layer solution approaches the one-layer solution;

3. turning off waterside turbulence in the one-layer scheme, which leads to the limiting behaviour $\alpha v_{\mathrm{dw}}=$ $\alpha(a D)^{1 / 2}$, makes the deposition velocity for the onelayer scheme without turbulence diverge further and further to become a very small fraction of the dry deposition velocity for the one-layer scheme with turbulence as SST or reactivity gets smaller;

4. except for cooler SSTs or lower reactivity, the twolayer scheme results in deposition velocity values that are even smaller than those from the one-layer scheme without turbulence for smaller values of $\delta_{m}$ (such $\delta_{m}$ values are obviously not realistic because the noturbulence behaviour is the lower limit); and

5. at the lower end of SST or reactivity values, there is a slight increase in $\alpha v_{\mathrm{dw}}$ with decreasing SST or reactivity, which is mostly due to the larger influence of solubility, which increases with decreasing temperature.

Sensitivity of $v_{\mathrm{dw}}$ to oceanic iodide concentration can also be explored. Based on their compilation of available measurements of sea surface iodide, covering latitudes $69^{\circ} \mathrm{S}-$ 

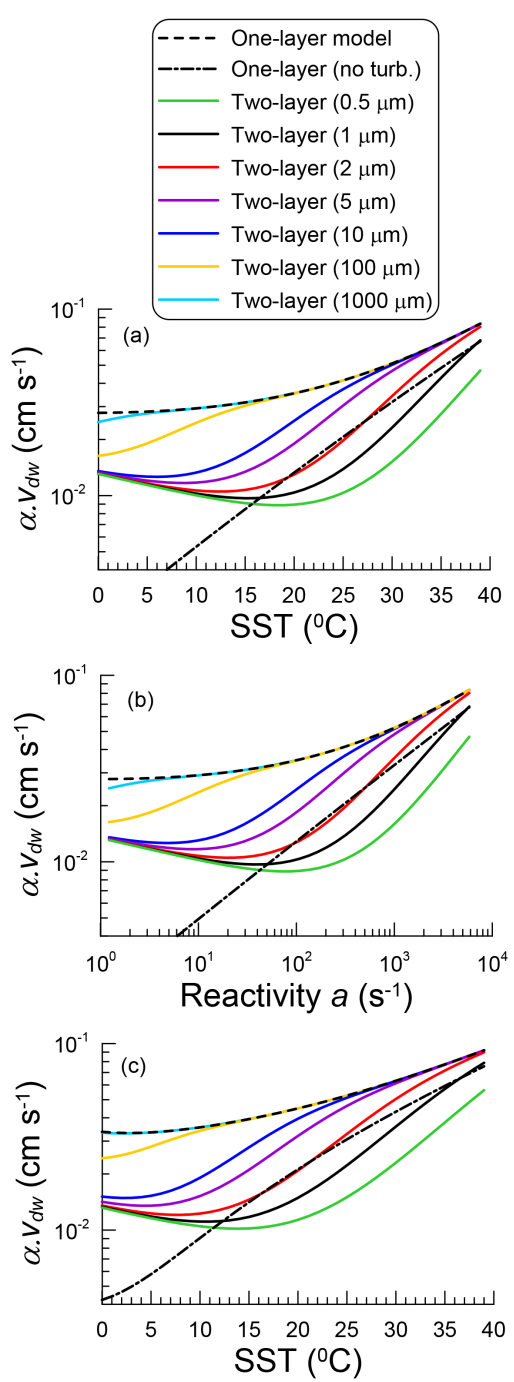

Figure 5. Variation of the oceanic component of ozone dry deposition velocity $\alpha v_{\mathrm{dw}}\left(=1 / r_{\mathrm{c}}\right)$ as a function of (a) sea surface temperature (SST, $\left.{ }^{\circ} \mathrm{C}\right)$ and $(\mathbf{b})$ reactivity $a\left(\mathrm{~s}^{-1}\right)$. Curves obtained using the one-layer reactivity deposition scheme with and without waterside turbulence, and the two-layer reactivity deposition scheme for a range of $\delta_{\mathrm{m}}$ values. Equation (12) was used for the iodide concentration, and the waterside friction velocity $\left(u_{* \mathrm{w}}\right)$ used was $0.01 \mathrm{~m} \mathrm{~s}^{-1}$. Plot (c) is the same as (a) except that Eq. (19) was used for the iodide concentration.

$66^{\circ} \mathrm{N}$, Chance et al. (2014) suggest the following parameterisation for iodide concentration in terms of SST:

$\left[\mathrm{I}^{-}\right](\mathrm{nM})=0.225\left(T_{\mathrm{s}}-273.16\right)^{2}+19$.

The iodide concentrations and also the reactivity values $(a)$ determined using Eq. (19) are higher by 207, 190, 154, 84, and $51 \%$ compared to Eq. (12) derived by MacDonald et al. (2014) for the SSTs of 5, 10, 20, 30, and $35^{\circ} \mathrm{C}$ respectively. Comparison of the curves in Fig. $5 \mathrm{c}$ obtained using Eq. (19) with those in Fig. 5a shows, as expected, that the values of $\alpha v_{\mathrm{dw}}$ are all higher in the former due to higher io- dide levels: the one-layer curve is higher by $18,21,27,24$, and $17 \%$, the no-turbulence curve is higher by $75,70,59$, 36 , and $23 \%$, and, as an example, the two-layer curve for $\delta_{m}=2 \mu \mathrm{m}$ is higher by $6,15,60,48$, and $25 \%$ for the temperatures above respectively. The two-layer curves from the two iodide concentration formulae require different $\delta_{m}$ values to be similar: for example, the curve for $\delta_{m}=2 \mu \mathrm{m}$ in Fig. 5c almost coincides with that for $\delta_{m}=5 \mu \mathrm{m}$ in Fig. 5a. We use the parameterisation Eq. (12) for iodide concentration in all subsequent calculations. Nevertheless, it is clear that the use of Eq. (19) in the one-layer scheme would not describe the data in Fig. 2a properly either.

Other sensitivity results show that as $u_{* \mathrm{w}}$ gets larger it requires larger values of $\delta_{m}$ to approach the one-layer behaviour, and that the solution obtained by the two-layer model approaches the one-layer model when $a_{0} \rightarrow a$.

\subsubsection{Comparison with data}

The two-layer reactivity scheme was incorporated into ACCESS-UKCA. The value of $\delta_{m}$ is selected based on the best agreement with data, given the constraint that it cannot be smaller than the reaction-diffusion length scale over which chemical reaction controls deposition. In other words, the variation of deposition yielded by a selected $\delta_{m}$ cannot be lower than the no-turbulence case (i.e. $K_{\mathrm{t}}=0$ ) for the same input conditions (see, e.g. Fig. 5). Based on the considerations above, a value of $\delta_{m}=2-3 \mu \mathrm{m}$ was found to be appropriate (which is of the order of the reaction-diffusion length scale) and we selected $\delta_{m}=2.5 \mu \mathrm{m}$. The model variation of $v_{\mathrm{d}}$ with SST determined using the two-layer reactivity scheme is presented in Fig. 6 along with the observed data. There is now a substantial improvement in the prediction of the observed $v_{\mathrm{d}}$ compared to the results from the default and one-layer schemes presented earlier. The modelled variation passes almost through the middle of the data. The variation of $v_{\mathrm{d}}$ with wind speed in Fig. 7 also shows considerable improvement over the previous model results, but as mentioned earlier the higher-end range of the modelled wind speed is smaller due to the fact that the wind extremes are averaged out in the modelled monthly averages. There is a relatively large scatter in the GOMECC07 predictions, but the modelled values for the rest of the experiments are similar to the measurements. These results imply that the two-layer scheme has the combined influences of solubility, molecular diffusion, chemical reaction, and turbulent transfer in better balance than the other two schemes.

The reason the two-layer scheme works is as follows. As mentioned earlier, there is an overestimation of the interaction between the chemical reaction term $(a)$ and the total diffusivity term $\left(D+K_{\mathrm{t}}\right)$ in Eq. (8) within the viscous sublayer because of the overestimation of $K_{\mathrm{t}}$ as a result of the assumption of its linearly increasing variation with depth. This leads to larger values of deposition velocity than observed. In the two-layer scheme, we effectively compensate for this over- 


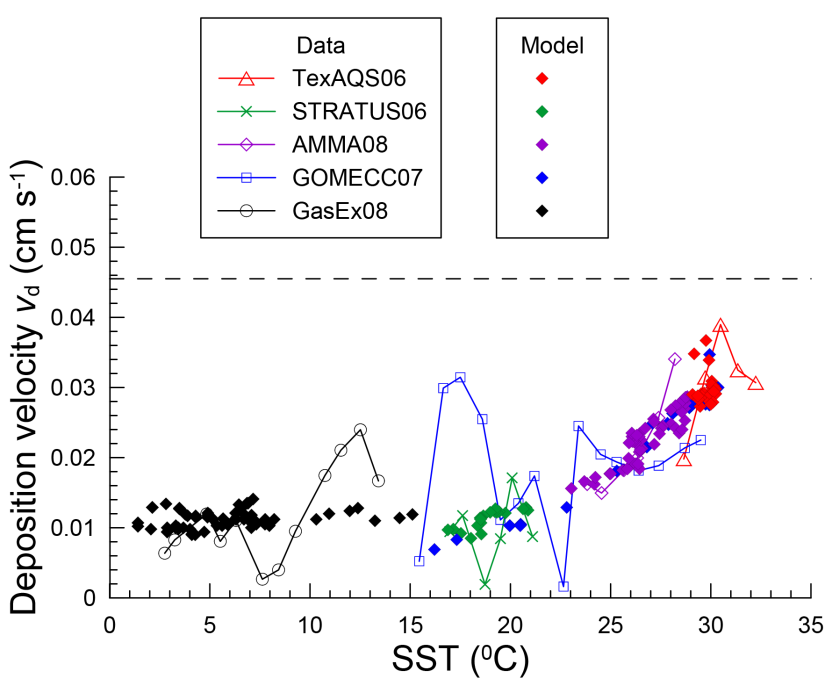

Figure 6. Ozone dry deposition velocity $\left(v_{\mathrm{d}}\right)$ as a function of sea surface temperature (SST) from five field experiments (Helmig et al., 2012; L. Bariteau, personal communication, 2016) and the corresponding values obtained from the ACCESS-UKCA model using the two-layer reactivity scheme for ozone deposition to the ocean.

estimation of turbulent transfer by constraining the extent of chemical reaction by limiting the iodide reactivity to a thickness of $\delta_{m}$ equivalent to the reaction-diffusion length scale even though in reality iodide is present through the depth of the oceanic surface layer.

There could be both overestimation and underestimation to some degree in the current reaction pathway for ozone within the ocean. Most of the chemistry underlying the kinetics has been studied at iodide concentrations varying from millimole per litre to mole per litre, whereas in the ocean the iodide concentration is approximately a million times more dilute, being in the nanomole per litre range. The fundamental step-by-step chemistry of ozone reaction with iodide has not been fully characterised. For example, if the bonding of the iodate complex in the reaction step involving ozone and iodide yielding iodate (Sakamoto et al., 2009) is weak, there could be a reverse reaction freeing the bound ozone. This is a speculative example of what could lead to a reduction in deposition rates. Conversely, reaction of ozone with compounds other than iodide in seawater could lead to a significant increase in deposition velocity. The analysis by Chang et al. (2004) considered reaction of ozone with iodide, dimethyl sulfide (DMS), ethene, and propene and showed that the reaction with iodide was by far the fastest of all (the reaction with DMS was comparably fast only when it was present at extremely high concentrations). In one of their model simulations, in addition to the reactions with iodide, DMS, and alkenes, Ganzeveld et al. (2009) also included ozone reaction with chlorophyll $a$ as a first-order approximation to examine the possible role of dissolved organic matter (DOM) (e.g. in coastal waters). They found that the inclusion of the

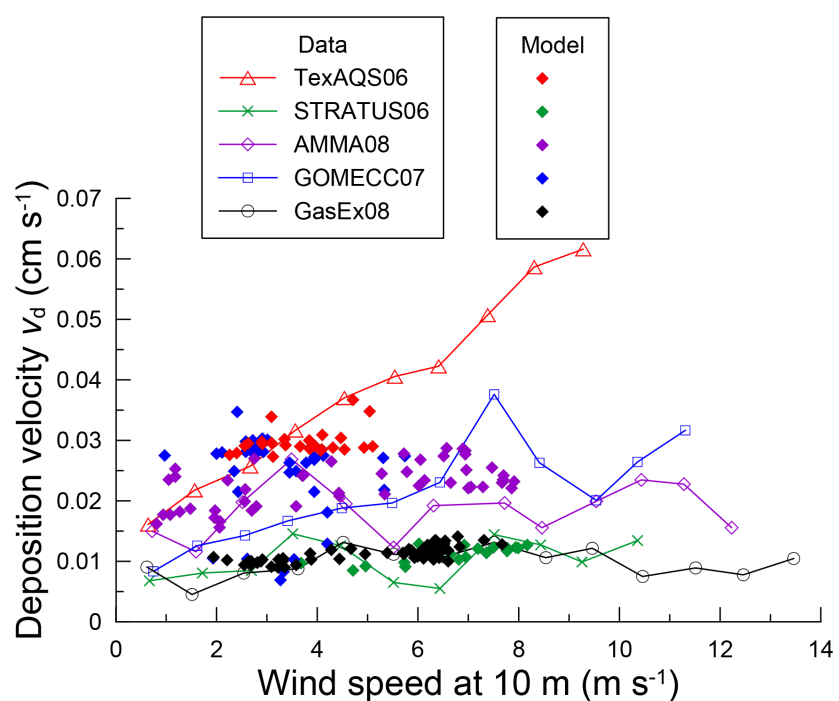

Figure 7. Ozone dry deposition velocity $\left(v_{\mathrm{d}}\right)$ as a function of wind speed at $10 \mathrm{~m}$ height from five field experiments (Helmig et al., 2012) and the corresponding values obtained from the ACCESSUKCA model using the two-layer reactivity scheme for ozone deposition to the ocean.

$\mathrm{O}_{3}$-chlorophyll $a$ chemistry in the model significantly increased deposition velocity at coastal sites but gave mixed results compared to observations. For open ocean sites, there were only small changes to deposition velocity. Clearly more observations of deposition velocity are needed for different oceanic regions to establish the relative role of additional ozone reactions in explaining the observed trends as well as related scatter.

Based on the comparison above with data from Helmig et al. (2012), the two-layer mechanism provides a good overall representation of the temperature dependence, wind-speed dependence, and absolute values of ozone deposition to the ocean. It is also sufficiently mathematically simple to require relatively little extra time to compute within the framework of the ACCESS chemistry-climate model.

\section{Global fields of ozone dry deposition velocity, loss, and concentration}

\subsection{Deposition velocity}

The modelled global distribution of ozone deposition velocity $\left(\mathrm{cm} \mathrm{s}^{-1}\right)$ averaged over the year 2006 in Fig. 8 shows that the two-layer reactivity scheme (Fig. 8a) gives the largest deposition velocities, as high as $0.03 \mathrm{~cm} \mathrm{~s}^{-1}$, in the tropics. $v_{\mathrm{d}}$ decreases with increasing latitude, but at around $60^{\circ} \mathrm{S}$ it slightly increases again, mainly due to the increase in ozone solubility with decreasing water temperature starting to exert more influence coupled with higher wind speeds in this latitudinal zone. From the tropics to mid-latitudes, the global 


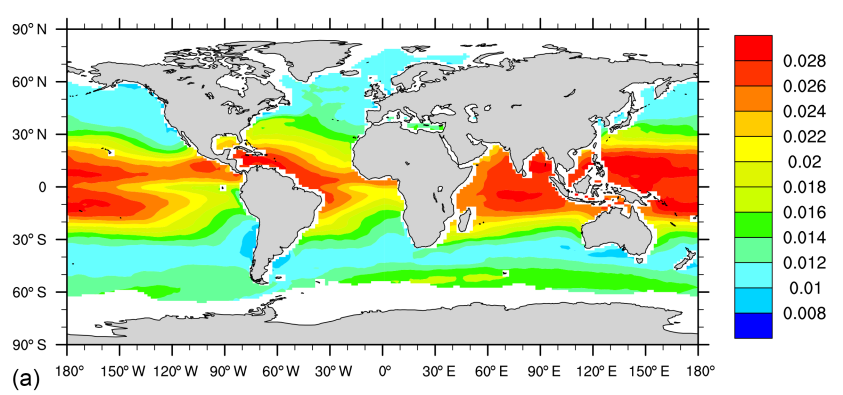

(a) $180^{\circ} \quad 150^{\circ} \mathrm{W} \quad 120^{\circ} \mathrm{W} \quad 90^{\circ} \mathrm{W} \quad 60^{\circ} \mathrm{W} \quad 30^{\circ} \mathrm{W} \quad 0^{\circ} \quad 30^{\circ} \mathrm{E} \quad 60^{\circ} \mathrm{E} \quad 90^{\circ} \mathrm{E} \quad 120^{\circ} \mathrm{E} \quad 150^{\circ} \mathrm{E} \quad 180^{\circ}$
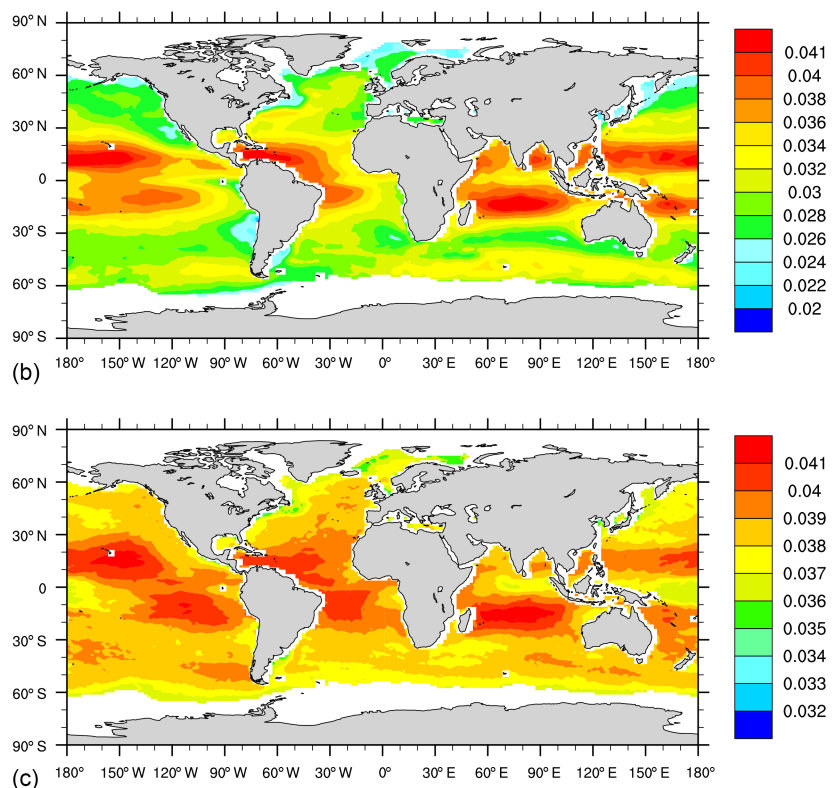

Figure 8. Modelled ozone dry deposition velocity $\left(v_{\mathrm{d}}, \mathrm{cm} \mathrm{s}^{-1}\right)$ averaged over the year 2006 obtained using the two-layer reactivity scheme (a), the one-layer reactivity scheme (b), and the default scheme with surface resistance $r_{\mathrm{c}}=2200 \mathrm{~s} \mathrm{~m}^{-1}$ (c). Note differences in scale.

distribution of $v_{\mathrm{d}}$ is qualitatively similar to the global SST distribution (plot not shown) because of the dominance of the ozone-iodide reaction in determining $v_{\mathrm{d}}$, in which iodide concentration has a proportional dependence on SST. The distribution from the one-layer reactivity scheme (Fig. 8b) is qualitatively similar to the two-layer result but with $v_{\mathrm{d}}$ values almost 2-3 times as large. The default ACCESS-UKCA scheme with $r_{\mathrm{c}}=2200 \mathrm{~s} \mathrm{~m}^{-1}$ (Fig. 8c) provides a much flatter variation of $v_{\mathrm{d}}$ across the globe. The magnitude of deposition velocity predicted by this scheme within the tropics is similar to that by the one-layer scheme, but beyond the tropics the values predicted by the constant surface resistance model are larger by a factor of approximately 2 .

The relative difference $(\%)$ between $v_{\mathrm{d}}$ predicted by the one-layer $\left(v_{\mathrm{d} 1}\right)$ and two-layer $\left(v_{\mathrm{d} 2}\right)$ reactivity schemes (defined as $\left.\left(v_{\mathrm{d} 1}-v_{\mathrm{d} 2}\right) \times 100 / v_{\mathrm{d} 2}\right)$ is presented in Fig. 9a, where differences as high as $150 \%$ can be seen in the mid-latitudes and as low as $25-50 \%$ in the tropics. The differences be-
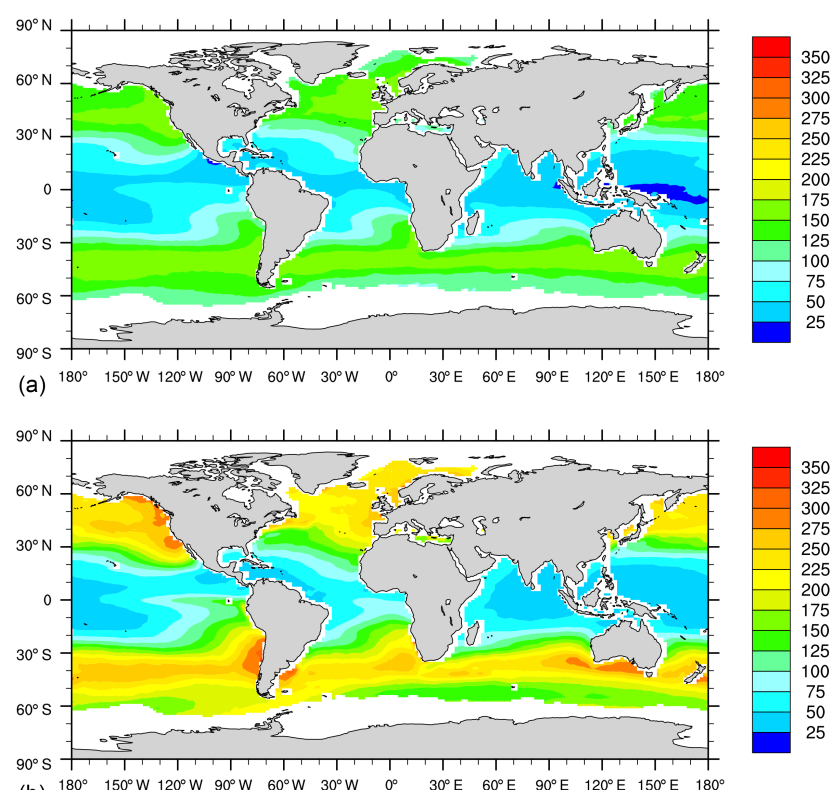

(b) $180^{\circ} 150^{\circ} \mathrm{W} 120^{\circ} \mathrm{W} \quad 90^{\circ} \mathrm{W} \quad 60^{\circ} \mathrm{W} \quad 30^{\circ} \mathrm{W} \quad 0^{\circ} \quad 30^{\circ} \mathrm{E} \quad 60^{\circ} \mathrm{E} \quad 90^{\circ} \mathrm{E} \quad 120^{\circ} \mathrm{E} \quad 150^{\circ} \mathrm{E} \quad 180^{\circ}$

Figure 9. Average relative difference (\%) for the year 2006 between the ozone dry deposition velocity $\left(v_{\mathrm{d}}, \mathrm{cm} \mathrm{s}^{-1}\right)$ modelled using the one-layer reactivity scheme and the two-layer reactivity scheme (a), and that between the default scheme (with surface resistance $r_{\mathrm{c}}=$ $2200 \mathrm{~s} \mathrm{~m}^{-1}$ ) and the two-layer reactivity scheme (b).

tween the default scheme and the two-layer reactivity scheme (Fig. 9b) in the mid-latitudes are even greater (up to $300 \%$ ).

In Table 1, the average deposition velocity for seawater (which excludes sea ice and coastal grid cells) obtained using the two-layer reactivity scheme is almost half that of the default scheme and two-thirds that of the one-layer scheme, which leads to a small lowering of the globally averaged value for the two-layer scheme. The averaged southern hemispheric deposition velocity values are generally lower than the northern hemispheric values. It is important to note that the two-layer model is the best fit to the available observational data. The observations as well as the model indicate the need for a decrease in the oceanic deposition velocities used for ozone in atmospheric chemistry models.

To explore seasonal differences, we plot Fig. 10 which is the same as Fig. 8 except that the left panels are for January 2006 and the right panels are for July 2006. The distributions are similar to the corresponding ones in Fig. 8 but there is more spatial variability in Fig. 10 because of shorter averaging (i.e. 1 month). For the two-layer scheme (top panels), in January the deposition velocities are generally larger in the mid- to high latitudes in the Northern Hemisphere than those in the Southern Hemisphere, and as expected, this behaviour is reversed in July mostly as a result of seasonal SST changes. For such latitudes in the Northern Hemisphere, the January deposition velocities are higher than those in July, and the reverse occurs in the Southern Hemisphere. In the tropics and subtropics, there is an upward latitudinal shift 
Table 1. Modelled average ozone dry deposition velocities for the year $2006\left(\mathrm{~cm} \mathrm{~s}^{-1}\right)$.

\begin{tabular}{|c|c|c|c|c|c|c|}
\hline \multirow[t]{2}{*}{ Deposition scheme } & \multicolumn{3}{|c|}{ Ocean } & \multicolumn{3}{|c|}{ Ocean, land, and ice } \\
\hline & $\begin{array}{c}\text { Northern } \\
\text { Hemisphere }\end{array}$ & $\begin{array}{c}\text { Southern } \\
\text { Hemisphere }\end{array}$ & Average & $\begin{array}{c}\text { Northern } \\
\text { Hemisphere }\end{array}$ & $\begin{array}{c}\text { Southern } \\
\text { Hemisphere }\end{array}$ & Average \\
\hline Two-layer & 0.020 & 0.017 & 0.018 & 0.097 & 0.051 & 0.074 \\
\hline One-layer & 0.033 & 0.032 & 0.032 & 0.104 & 0.062 & 0.083 \\
\hline Default (constant $r_{\mathrm{c}}$ ) & 0.039 & 0.039 & 0.039 & 0.108 & 0.067 & 0.087 \\
\hline
\end{tabular}

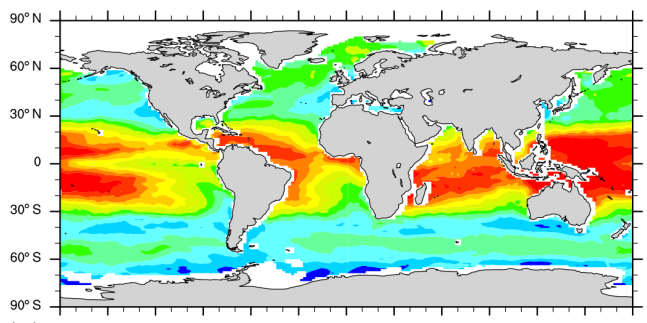

(a) $180^{\circ} \quad 150^{\circ} \mathrm{W} 120^{\circ} \mathrm{W} \quad 90^{\circ} \mathrm{W} \quad 60^{\circ} \mathrm{W} \quad 30^{\circ} \mathrm{W} \quad 0^{\circ} \quad 30^{\circ} \mathrm{E} \quad 60^{\circ} \mathrm{E} \quad 90^{\circ} \mathrm{E} \quad 120^{\circ} \mathrm{E} \quad 150^{\circ} \mathrm{E} \quad 180^{\circ}$

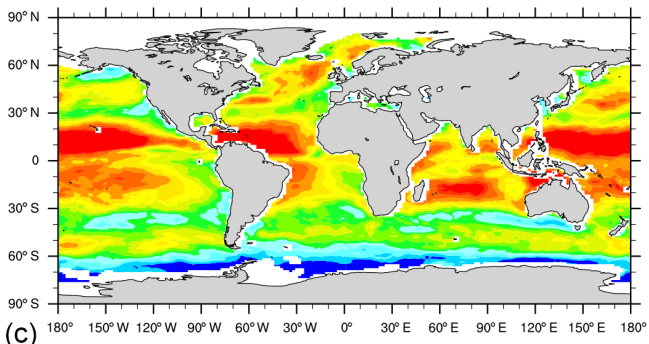

(C)

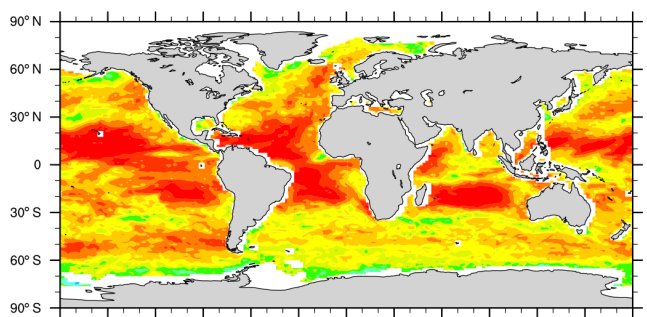

(e)
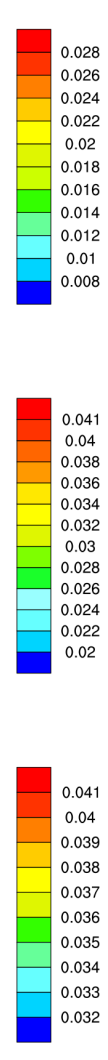

(f)

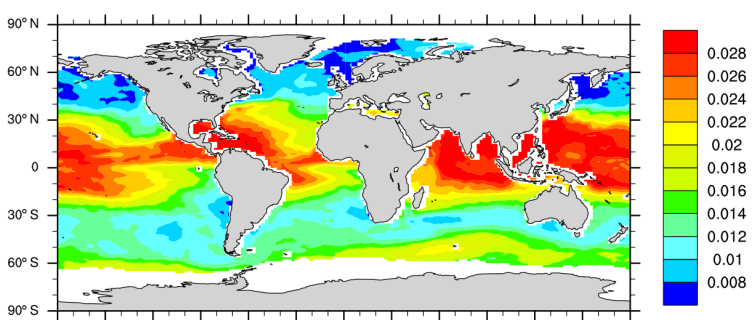

(b) $180^{\circ} \quad 150^{\circ} \mathrm{W} 120^{\circ} \mathrm{W} \quad 90^{\circ} \mathrm{W} \quad 60^{\circ} \mathrm{W} \quad 30^{\circ} \mathrm{W} \quad 0^{\circ} \quad 30^{\circ} \mathrm{E} \quad 60^{\circ} \mathrm{E} \quad 90^{\circ} \mathrm{E} \quad 120^{\circ} \mathrm{E} \quad 150^{\circ} \mathrm{E} \quad 180^{\circ}$

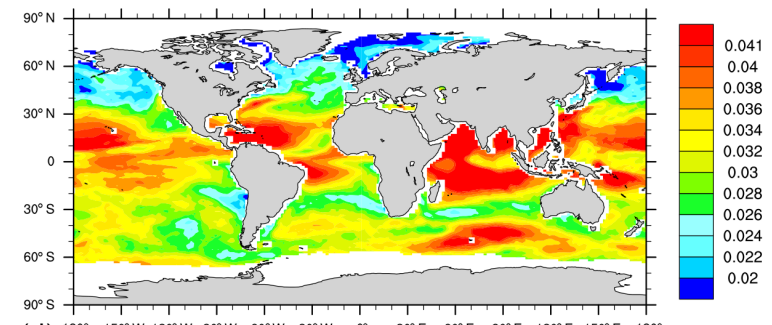

(d) $180^{\circ} \quad 150^{\circ} \mathrm{W} 120^{\circ} \mathrm{W} \quad 90^{\circ} \mathrm{W} \quad 60^{\circ} \mathrm{W} \quad 30^{\circ} \mathrm{W} \quad 0^{\circ} \quad 30^{\circ} \mathrm{E} \quad 60^{\circ} \mathrm{E} \quad 90^{\circ} \mathrm{E} \quad 120^{\circ} \mathrm{E} \quad 150^{\circ} \mathrm{E} \quad 180^{\circ}$

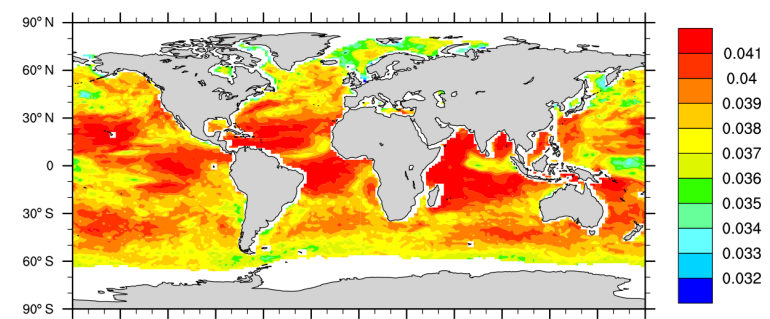

(f) $180^{\circ} \quad 150^{\circ} \mathrm{W} 120^{\circ} \mathrm{W} \quad 90^{\circ} \mathrm{W} \quad 60^{\circ} \mathrm{W} \quad 30^{\circ} \mathrm{W} \quad 0^{\circ} \quad 30^{\circ} \mathrm{E} \quad 60^{\circ} \mathrm{E} \quad 90^{\circ} \mathrm{E} \quad 120^{\circ} \mathrm{E} \quad 150^{\circ} \mathrm{E} \quad 180^{\circ}$

Figure 10. Modelled ozone dry deposition velocity $\left(v_{\mathrm{d}}, \mathrm{cm} \mathrm{s}^{-1}\right)$. The left panels $(\mathbf{a}, \mathbf{c}, \mathbf{e})$ are for January 2006 and right panels $(\mathbf{b}, \mathbf{d}, \mathbf{f})$ are for July 2006. Top panels (a, b) are from the two-layer reactivity scheme, middle panels (c, d) are from the one-layer reactivity scheme, and bottom panels $(\mathbf{e}, \mathbf{f})$ are from the default scheme with surface resistance $r_{\mathrm{c}}=2200 \mathrm{~s} \mathrm{~m}^{-1}$. Note differences in scale.

of high-deposition-velocity regions in July compared to January. In qualitative terms, the behaviour above is also evident in the results from the one-layer scheme (middle panels). For the default scheme (bottom panels), the seasonal variations in $v_{\mathrm{d}}$ are smaller and less apparent and would be mainly dominated by seasonal wind-speed variations. In all plots, the white region around the poles is the extent of sea ice, which is larger in July around the South Pole and in January around the North Pole.

Ganzeveld et al. (2009) presented January and July deposition velocities simulated using the one-layer reactivity scheme in their free-running ECHAM5/MESSy climate- chemistry model (see their Fig. 3a and b respectively). Their plots are significantly different to the corresponding middle panels in Fig. 10. Our results show maximum values of deposition velocity in the tropics and subtropics (largely as a result of enhancement due to chemical reaction because of higher iodide associated with higher SSTs), whereas the maxima in their plots are mostly located in mid-latitudes, which they attribute to high wind speeds in the storm track regions located at such latitudes. Apart from potentially significant differences in the formulation of the two climatechemistry models, there are other differences as well, such 
as resolution, use of nudging in our model, emissions, and the parameterisation of iodide concentration.

\subsection{Ozone loss}

The modelled global distribution of dry deposition velocity to the ocean can be combined with the modelled ozone concentration fields to enable the loss of ozone to the ocean surface to be estimated. The deposition budgets obtained using ACCESS-UKCA are presented in Table 2. Compared to the default scheme, the global ozone deposition to seawater, excluding sea ice and coastal grid cells, is $85 \%$ for the one-layer reactivity scheme and it is almost halved for the two-layer reactivity scheme. Deposition to the sea is $12 \%$ of the total deposition for the two-layer scheme, $19 \%$ for the one-layer scheme, and $21 \%$ for the default scheme. The reduction in oceanic deposition using the two-layer scheme corresponds to a $10 \%$ decrease in the total global estimate of ozone deposition relative to the original (default) scheme, and this is consistent with the current observations of deposition velocity to the ocean surface. The seawater deposition in the Northern Hemisphere is slightly larger than that in the Southern Hemisphere due to the higher average seawater deposition velocity in the former (Table 1). Of the total global ozone deposition, about $70 \%$ is in the Northern Hemisphere and $30 \%$ is in the Southern Hemisphere, the former being larger due to the much larger terrestrial contribution. The total ozone deposition obtained from ACCESS-UKCA is on the lower end of the values reported from other models: $1094 \pm 264 \mathrm{Tg} \mathrm{yr}^{-1}$ (Young et al., 2013), $1003 \pm 200 \mathrm{Tg} \mathrm{yr}^{-1}$ (Stevenson et al., 2006), and $949 \pm 222 \mathrm{Tg} \mathrm{yr}^{-1}$ (Wild, 2007) (see also Climate Change, The Physical Science Basis, 2013, IPCC, AR5, Chapter 8, Anthropogenic and Natural Radiative Forcing, Table 8.1, p. 672; Young et al., 2013). This is likely due to the general underestimation of tropospheric ozone by ACCESS-UKCA (Woodhouse et al., 2015), the exact reason(s) for which we have not been able to pinpoint but they are an ongoing area of study. An underestimation of ozone would result in an underestimation of the ozone dry deposition flux near the surface. However, the calculated deposition velocity is not influenced by the predicted ozone concentration; thus, the relative dry deposition budget contributions given above in terms of percentages should remain representative.

These relative decreases in ozone oceanic deposition, calculated here with the two-layer model, are not model artefacts, but through the model validation process, are based on the best available representation of the observations of oceanic ozone deposition rates available today.

\subsection{Ozone concentration}

While we have previously noted that ACCESS-UKCA underestimates tropospheric ozone, it is worthwhile to examine how an oceanic dry deposition parameterisation af- fects tropospheric ozone distributions. Figure 11a shows the modelled annual, near-surface (at $20 \mathrm{~m}$ ) ozone concentration (ppbv) based on the two-layer reactivity scheme. Relatively high concentrations in the Northern Hemisphere, especially within $0-50^{\circ} \mathrm{N}$, are evident, which can be related to the larger precursor emissions in these regions. Figure $11 \mathrm{~b}$ presents the relative difference $(\%)$ between the ozone concentration predicted by the one-layer $\left(c_{1}\right)$ and two-layer $\left(c_{2}\right)$ reactivity schemes (defined as $\left.\left(c_{1}-c_{2}\right) \times 100 / c_{2}\right)$. It can be seen that the largest underestimation of the near-surface ozone concentration by the one-layer scheme is $11 \%$ for $45-$ $70^{\circ} \mathrm{S}$. Figure $11 \mathrm{c}$ is the relative difference between the concentration predicted by the default scheme and the two-layer reactivity scheme, which shows the largest underestimation by the default scheme of $17 \%$ within the same latitudinal band. Figure $11 \mathrm{c}$ can be approximately compared with the results in Fig. 10 of the paper by Ganzeveld et al. (2009) in which they present the relative difference between a constant $r_{\mathrm{c}}$ scheme (with $r_{\mathrm{c}}=2000 \mathrm{~s} \mathrm{~m}^{-1}$ ) and the one-layer scheme. The largest underestimation by their constant $r_{\mathrm{c}}$ scheme is about $4 \%$ in the latitudes $45-70^{\circ} \mathrm{S}$; this latitudinal band is very similar to what is suggested by the present results but with an underestimation of $17 \%$. Their results show that there is also a significant overestimation by their constant $r_{\mathrm{c}}$ scheme, the largest of which is about $4 \%$ over the tropical and subtropical $\left(30^{\circ} \mathrm{S}-30^{\circ} \mathrm{N}\right)$ waters and in high-latitude regions in the Northern Hemisphere. This, however, is not apparent in our results.

We also examine the influence of the various schemes on the modelled ozone distribution throughout the troposphere. Figure 12a is the observed zonal distribution of ozone concentration as a function of altitude for the year 2006 based on the monthly mean ozone profile database available from and described at http://www.bodekerscientific.com/data/ monthly-mean-global-vertically-resolved-ozone. These gap-filled data (Tier 1.4) are based on the raw individual ozone data sourced from the so-called Binary Database of Profiles (BDBP) (Hassler et al., 2009) and cover the whole globe. Figure $12 \mathrm{~b}$ is the corresponding distribution obtained from ACCESS-UKCA using the two-layer reactivity scheme. There are similarities between the observed and modelled fields; for example, the tropospheric ozone levels are lower in the Southern Hemisphere in both plots. The high ozone concentration areas at the top corners correspond to the lower edges of the stratosphere, which start at an altitude of about $10 \mathrm{~km}$ at the poles and increase to about $15 \mathrm{~km}$ at the Equator. In the troposphere, the modelled concentrations are generally lower compared to the observations, for example in the high latitudes, which is a known feature of the model (Woodhouse et al., 2015). This is more clearly evident in Fig. 12c, which presents the relative difference $(=[(\bar{M}-\bar{O}) / \bar{O}] \times 100 \%)$ between the time-averaged modelled concentration $(\bar{M})$ determined using the two-layer reactivity scheme and the time-averaged 
Table 2. Modelled ozone dry deposition for the year $2006\left(\mathrm{Tg} \mathrm{yr}^{-1}\right)$.

\begin{tabular}{|c|c|c|c|c|c|c|}
\hline \multirow[t]{2}{*}{ Deposition scheme } & \multicolumn{3}{|c|}{ Ocean } & \multicolumn{3}{|c|}{ Ocean, land, and ice } \\
\hline & $\begin{array}{c}\text { Northern } \\
\text { Hemisphere }\end{array}$ & $\begin{array}{c}\text { Southern } \\
\text { Hemisphere }\end{array}$ & Global & $\begin{array}{c}\text { Northern } \\
\text { Hemisphere }\end{array}$ & $\begin{array}{l}\text { Southern } \\
\text { Hemisphere }\end{array}$ & Global \\
\hline Two-layer & 44.8 & 37.7 & 82.5 & 500.5 & 209.2 & 709.7 \\
\hline One-layer & 76.5 & 67.5 & 144.0 & 530.4 & 237.7 & 768.1 \\
\hline Default (constant $r_{\mathrm{c}}$ ) & 89.2 & 78.5 & 167.7 & 541.5 & 248.0 & 789.5 \\
\hline
\end{tabular}

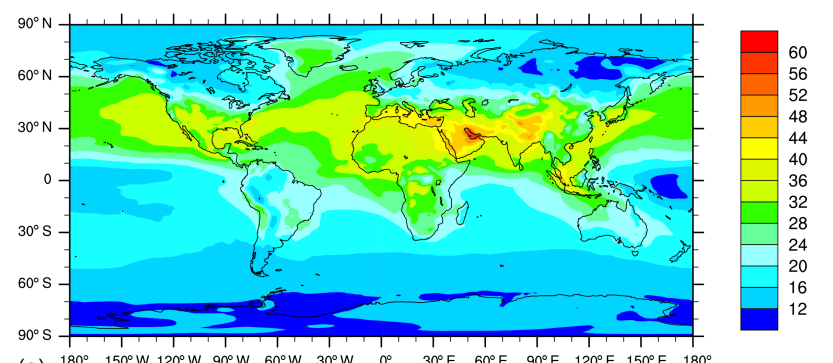

(a) $180^{\circ} \quad 150^{\circ} \mathrm{W} 120^{\circ} \mathrm{W} \quad 90^{\circ} \mathrm{W} \quad 60^{\circ} \mathrm{W} \quad 30^{\circ} \mathrm{W} \quad 0^{\circ} \quad 30^{\circ} \mathrm{E} \quad 60^{\circ} \mathrm{E} \quad 90^{\circ} \mathrm{E} \quad 120^{\circ} \mathrm{E} \quad 150^{\circ} \mathrm{E} \quad 180^{\circ}$
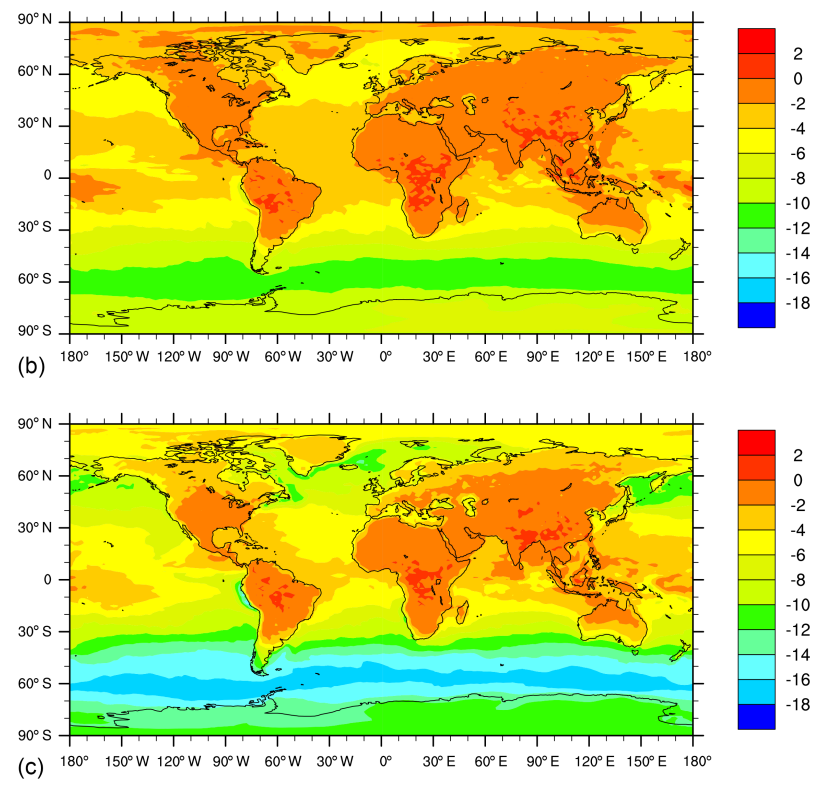

Figure 11. (a) Modelled annual ozone concentration (ppbv) for 2006 obtained using the two-layer reactivity scheme; (b) average relative difference $(\%)$ between the ozone concentration predicted using the one-layer reactivity scheme and the two-layer reactivity scheme; and (c) average relative difference (\%) between the ozone concentration predicted using the default scheme with surface resistance $r_{\mathrm{c}}=2200 \mathrm{~s} \mathrm{~m}^{-1}$ and the two-layer reactivity scheme.

observed concentration $(\bar{O})$. Figure $12 \mathrm{~d}$ is the same plot except for the default scheme. There are improvements in the ozone prediction with the two-layer scheme south of $40^{\circ} \mathrm{S}$, both at the lowest altitudes and at upper levels as high as $6 \mathrm{~km}$. There is also some improvement in the tropical south at a height of about $8 \mathrm{~km}$. There is a slight model improvement in the high latitudes $70-80^{\circ} \mathrm{N}$ between the altitudes 2 and $6 \mathrm{~km}$. Overall, for the latitudes $45-70^{\circ} \mathrm{S}$, the two-layer scheme improves the prediction of the observed zonal ozone mixing ratios at an altitude of $1 \mathrm{~km}$ by $7 \%$ compared to the original default scheme. For the altitude range $1-6 \mathrm{~km}$, this improvement is $5 \%$.

\section{Conclusions}

Ozone dry deposition parameterisation schemes are best evaluated within an integrated modelling framework that includes multi-parameter interdependencies of deposition as exist in the field. Using recent measurements, we assessed the performance of three ozone dry deposition schemes for seawater within the global climate-chemistry model ACCESS-UKCA, incorporating meteorological nudging and monthly-varying emissions. The default scheme assumes a constant water surface resistance of $2200 \mathrm{~s} \mathrm{~m}^{-1}$, which is commonly used in most atmospheric chemistry-composition models. The second scheme is a mechanistic, one-layer reactivity scheme proposed by Fairall et al. (2007) in which the surface resistance formulation includes the simultaneous influence of ozone solubility in water, waterside molecular diffusion and turbulent transfer, and a first-order chemical reaction of ozone with dissolved iodide. The third scheme is a development of the two-layer reactivity scheme from Fairall et al. (2007) in which, unlike the uniform reactivity assumption in the one-layer scheme, the water surface has a high reactivity and the region below has a very small background reactivity.

A comparison of the observed deposition velocity dependencies on sea surface temperature and wind speed with those obtained from ACCESS-UKCA using the three schemes showed that the two-layer scheme is able to describe the absolute magnitude and the sea surface temperature and wind-speed dependence of the field measurements most closely. The two-layer scheme results are sensitive to the value of the thickness of the surface reactive layer. A value between 2 and $3 \mu \mathrm{m}$, which is about the same as the typical reaction-diffusion length scale over which the ozone-iodide chemical reaction dominates deposition, provides good estimates of deposition and we chose $2.5 \mu \mathrm{m}$. The assumption in the first scheme of a constant water surface resistance overestimates the observed deposition velocity by 


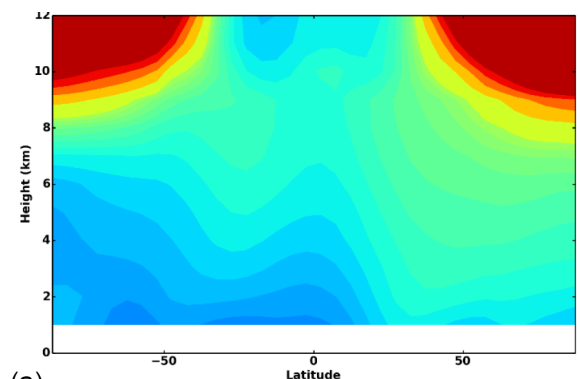

(a)

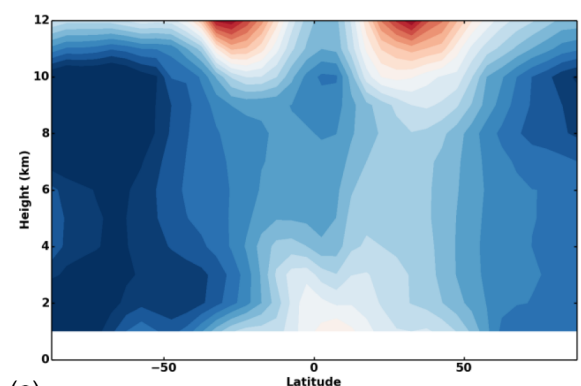

(c)

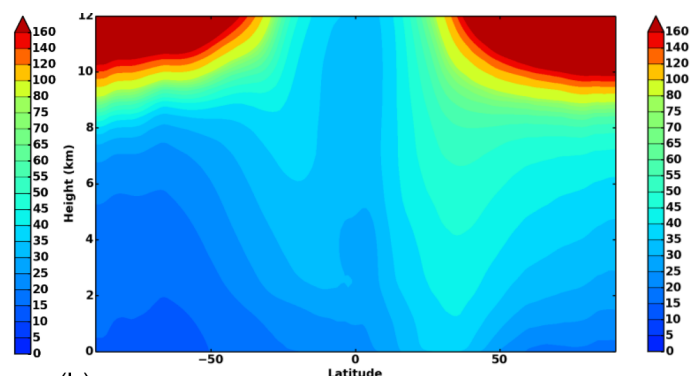

(b)

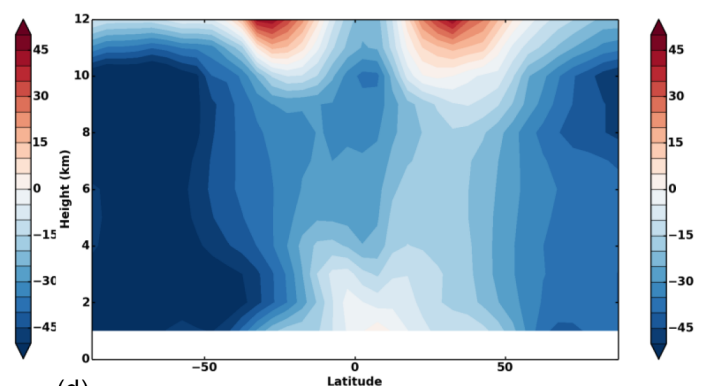

(d)

Figure 12. Zonal distribution of ozone concentration (ppbv) for the year 2006. (a) Observed distribution based on the global monthly mean vertical ozone profile database available from http://www.bodekerscientific.com; (b) the corresponding ACCESS-UKCA model distribution using the two-layer reactivity scheme; (c) the relative difference $(\%)$ between the modelled concentration determined using the two-layer reactivity scheme and the observations; and (d) the relative difference (\%) between the modelled concentration determined using the default scheme and the observations.

a factor of 2-4 and does not describe its variability with SST and wind speed. The one-layer scheme performs somewhat better than the default scheme. Although the one-layer scheme includes all the same important processes as the twolayer scheme, it still overestimates the observed deposition velocity by a factor of 2-3 when the reaction is slow under colder SSTs. The likely reason for this problem is an overestimation of the influence of waterside turbulent transfer on chemical reaction via the assumption that turbulent diffusivity is a linear function of depth. This assumption, valid for a fully turbulent flow, overestimates turbulent transfer in the viscous sublayer (within which the bulk of the ozone-iodide reaction takes place) because it does not account for the viscous dissipation of turbulence in this layer. The two-layer reactivity scheme limits the dissolved iodide concentration to a specified depth from the water surface, thereby restricting the ozone-iodide reaction and its interaction with turbulence to that depth. Although this restriction is artificial, it works as surrogate to compensate for the overestimation of turbulent transfer in the viscous sublayer. A better parameterisation of turbulent mixing near the interface in the concentration conservation equation could overcome the issue.

The modelled global distributions show that the two-layer reactivity scheme yields maximum ozone deposition velocities in the tropics, which decrease with increasing latitude and then increase again slightly in the Southern Hemisphere. Significant local variations are also evident. This latitudinal behaviour is the result of the combined effects of chemical re- action, solubility, molecular diffusion, and turbulent transfer, and because all these processes except for turbulent transfer are direct functions of SST, which in turn is a function of latitude, there is a strong latitudinal dependence.

Previous model estimates in the scientific literature suggest that approximately one-third of the total ozone dry deposition is to the ocean. The deposition velocities obtained using the two-layer scheme and also the recent oceanic ozone deposition observations point to a substantially lower ozone deposition to the ocean. A new modelled estimate of ozone deposition to the ocean (which excludes sea ice and coastal grid cells) is almost half of the original oceanic deposition obtained using the default scheme and corresponds to a $10 \%$ decrease in the total global estimate of ozone deposition relative to the original (default) scheme, making a significant relative change to the overall tropospheric ozone budget. Although it does not influence the modelled deposition velocity, the underestimation of tropospheric ozone by ACCESSUKCA needs to be investigated since it leads to a lower absolute value of annual global deposition.

The effects of the choice of a deposition scheme in the global model were noticeable in the predicted atmospheric ozone mixing ratios, especially in the Southern Hemisphere. For the latitudes $45-70^{\circ} \mathrm{S}$, the two-layer scheme improved the ozone predictions near the surface by $7 \%$ and those within the altitude range $1-6 \mathrm{~km}$ by $5 \%$ compared to the original default scheme. 
Based on all the evaluation results presented above, the two-layer reactivity scheme as formulated in this paper is the best performing scheme, compared to the available observations, for describing ozone deposition to seawater in a global modelling framework.

Further observations on deposition velocity with greater temporal and spatial coverage would help constrain oceanic dry deposition schemes better. Such work would also look at potential improvement on the parameterisation of iodide in terms of physical and chemical properties of seawater and an assessment of the relative impact of any additional chemical reactions to ozone uptake at sea surface. Studies involving observations of the sea surface microlayer, the role of wave breaking and bubbles on deposition processes, and the degree of relevant feedbacks in climate-chemistry models (e.g. the ozone reaction with oceanic iodide, which produces iodine compounds that participate in atmospheric ozone destruction cycles in the troposphere) need to be explored.

Data availability. The global-model output data (in NetCDF format) used for analysis and plotting, and the processed model deposition data (in ASCII format) used for comparison with observations can be made available by contacting the corresponding author (Ashok Luhar: ashok.luhar@csiro.au).

Competing interests. The authors declare that they have no conflict of interest.

Acknowledgements. This work was supported by funding from the Australian Climate Change Science Programme (ACCSP). This research was undertaken with the assistance of resources and services from the National Computational Infrastructure (NCI), which is supported by the Australian government. Communication with Chris Fairall, Detlev Helmig, Laurens Ganzeveld, and Rosie Chance concerning their works was very useful. We are indebted to Ludovic Bariteau for kindly supplying data related to their published work. Fiona O'Connor, Mohit Dalvi, Steve Rumbold, and Colin Johnson of the U.K. Met Office are thanked for their assistance with the UKCA emission methodology and for answering questions about UM-UKCA. Luke Abraham of the University of Cambridge is thanked for his help with several technical questions about UKCA. Martin Dix and Scott Wales are acknowledged for their help with model configuration issues, and Lauren Stevens is acknowledged for help with emission data. ERA-Interim data from the European Centre for Medium-Range Weather Forecasts was used in this research. We would like to thank Greg Bodeker (Bodeker Scientific) and Birgit Hassler (NOAA) for providing the combined vertical ozone profile database. We thank the two reviewers and co-editor for their helpful comments.

Edited by: L. Ganzeveld

Reviewed by: C. Fairall and one anonymous referee

\section{References}

Abraham, N. L., Archibald, A. T., Bellouin, N., Boucher, O., Braesicke, P., Bushell, A., Carslaw, K. S., Collins, W., Dalvi, M., Emmerson, K. M., Folberth, G., Haywood, J., Johnson, C., Kipling, Z., Macintyre, H., Mann, G. W., Telford, P. J., Merikanto, J., Morgenstern, O., O’Connor, F., Ordonez, C., Osprey, S., Pringle, K. J., Pyle, J. A., Rae, J. G. L., Reddington, C. L., Savage, D., Spracklen, D., Stier, P., and West, R.: Unified Model Documentation Paper No. 84: United Kingdom Chemistry and Aerosol (UKCA) Technical Description MetUM Version 8.4, UK Met Office, Exeter, UK, 74 pp., 2012.

Bi, D. H., Dix, M., Marsland, S. J., O'Farrell, S., Rashid, H. A., Uotila, P., Hirst, A. C., Kowalczyk, E., Golebiewski, M., Sullivan, A., Yan, H. L., Hannah, N., Franklin, C., Sun, Z. A., Vohralik, P., Watterson, I., Zhou, X. B., Fiedler, R., Collier, M., Ma, Y. M., Noonan, J., Stevens, L., Uhe, P., Zhu, H. Y., Griffies, S. M., Hill, R., Harris, C., and Puri, K.: The ACCESS coupled model: description, control climate and evaluation, Australian Meteorological and Oceanographic Journal, 63, 41-64, 2013.

Carpenter, L. J., MacDonald, S. M., Shaw, M. D., Kumar, R., Saunders, R. W., Parthipan, R., Wilson, J., and Plane, J. M. C.: Atmospheric iodine levels influenced by sea surface emissions of inorganic iodine, Nat. Geosci., 6, 108-111, doi:10.1038/NGEO1687, 2013.

Carpenter, L. J. and Nightingale, P. D.: Chemistry and release of gases from the surface ocean, Chem. Rev., 115, 4015-4034, doi:10.1021/cr5007123, 2015.

Chance, R., Baker, A. R., Carpenter, L., and Jickells, T. D.: The distribution of iodide at the sea surface, Environmental Science: Processes \& Impacts, 16, 1841-1859, doi:10.1039/c4em00139g, 2014.

Chang, W. N., Heikes, B. G., and Lee, M.: Ozone deposition to the sea surface: Chemical enhancement and wind speed dependence, Atmos. Environ., 38, 1053-1059, doi:10.1016/j.atmosenv.2003.10.050, 2004.

Emmons, L. K., Walters, S., Hess, P. G., Lamarque, J.-F., Pfister, G. G., Fillmore, D., Granier, C., Guenther, A., Kinnison, D., Laepple, T., Orlando, J., Tie, X., Tyndall, G., Wiedinmyer, C., Baughcum, S. L., and Kloster, S.: Description and evaluation of the Model for Ozone and Related chemical Tracers, version 4 (MOZART-4), Geosci. Model Dev., 3, 43-67, doi:10.5194/gmd3-43-2010, 2010.

Fairall, C. W., Hare, J. E., Edson, J. B., and McGillis, W.: Parameterization and micrometeorological measurements of air-sea gas transfer, Bound.-Lay. Meteorol., 96, 63-105, doi:10.1023/A:1002662826020, 2000.

Fairall, C. W., Helmig, D., Ganzeveld, L., and Hare, J.: Waterside turbulence enhancement of ozone deposition to the ocean, Atmos. Chem. Phys., 7, 443-451, doi:10.5194/acp-7-443-2007, 2007.

Fairall, C. W., Yang, M., Bariteau, L., Edson, J., Helmig, D., McGillis, W., Pezoa, S., Hare, J. E., Huebert, B., and Blomquist, B.: Implementation of the coupled ocean-atmosphere response experiment flux algorithm with $\mathrm{CO}_{2}$, dimethyl sulfide, and $\mathrm{O}_{3}$, J. Geophys. Res., 116, C00F09, doi:10.1029/2010JC006884, 2011.

Galbally, I. E. and Roy, C. R.: Destruction of ozone at the Earth's surface, Q. J. Roy. Meteor. Soc., 106, 599-620, doi:10.1002/qj.49710644915, 1980. 
Galbally, I. E., Bentley, S. T., and Meyer, C. P.: Mid-latitude marine boundary-layer ozone destruction at visible sunrise observed at Cape Grim, Tasmania, $41^{\circ} \mathrm{S}$, Geophys. Res. Lett., 27, 38413844, doi:10.1029/1999GL010943, 2000.

Ganzeveld, L., Helmig, D., Fairall, C., Hare, J. E., and Pozzer, A.: Atmosphere-ocean ozone exchange: A global modeling study of biogeochemical, atmospheric and water-side turbulence dependencies, Global Biogeochem. Cy., 23, GB4021, doi:10.1029/2008GB003301, 2009.

Garland, J. A., Elzerman, A. W., and Penkett, S. A.: The mechanism for dry deposition of ozone to seawater surfaces, J. Geophys. Res., 85, 7488-7492, doi:10.1029/JC085iC12p07488, 1980.

Hardacre, C., Wild, O., and Emberson, L.: An evaluation of ozone dry deposition in global scale chemistry climate models, Atmos. Chem. Phys., 15, 6419-6436, doi:10.5194/acp-15-64192015, 2015.

Hassler, B., Bodeker, G. E., Cionni, I., and Dameris, M.: A vertically resolved, monthly mean, ozone database from 1979 to 2100 for constraining global climate model simulations, Int. J. Remote Sens., 30, 4009-4018, doi:10.1080/01431160902821874, 2009.

Helmig, D., Lang, E. K., Bariteau, L., Boylan, P., Fairall, C. W., Ganzeveld, L., Hare, J. E., Hueber, J., and Pallandt, M.: Atmosphere-ocean ozone fluxes during the TexAQS 2006, STRATUS 2006, GOMECC 2007, GasEx 2008, and AMMA 2008 cruises, J. Geophys. Res., 117, D04305, doi:10.1029/2011JD015955, 2012.

Hicks, B. B., Baldocchi, D. D., Meyers, T. P., Hosker Jr., R. P., and Matt, D. R.: A preliminary multiple resistance routine for deriving dry deposition velocities from measured quantities, Water Air Soil Poll., 36, 311-330, doi:10.1007/BF00229675, 1987.

IPCC: Climate Change 2013: The Physical Science Basis, Contribution of Working Group I to the Fifth Assessment Report of the Intergovernmental Panel on Climate Change, edited by: Stocker, T. F., Qin, D., Plattner, G.-K., Tignor, M., Allen, S. K., Boschung, J., Nauels, A., Xia, Y., Bex, V., and Midgley, P. M., Cambridge University Press, Cambridge, United Kingdom and New York, NY, USA, 1535 pp., 2013.

Johnson, P. N. and Davis, R. A.: Diffusivity of ozone in water, J. Chem. Eng. Data, 41, 1485-1487, doi:10.1021/je9602125, 1996.

Kerkweg, A., Buchholz, J., Ganzeveld, L., Pozzer, A., Tost, H., and Jöckel, P.: Technical Note: An implementation of the dry removal processes DRY DEPosition and SEDImentation in the Modular Earth Submodel System (MESSy), Atmos. Chem. Phys., 6, 4617-4632, doi:10.5194/acp-6-4617-2006, 2006.

Lamarque, J.-F., Emmons, L. K., Hess, P. G., Kinnison, D. E., Tilmes, S., Vitt, F., Heald, C. L., Holland, E. A., Lauritzen, P. H., Neu, J., Orlando, J. J., Rasch, P. J., and Tyndall, G. K.: CAMchem: description and evaluation of interactive atmospheric chemistry in the Community Earth System Model, Geosci. Model Dev., 5, 369-411, doi:10.5194/gmd-5-369-2012, 2012.

Liss, P. and Merlivat, L.: Air-gas exchange rate: introduction and synthesis, in: The Role of Air-Sea Exchange in Geochemical Cycling, edited by: Buat-Menard, P., D. Reidel, Hingham, MA, 113-129, 1986.

MacDonald, S. M., Gómez Martín, J. C., Chance, R., Warriner, S., Saiz-Lopez, A., Carpenter, L. J., and Plane, J. M. C.: A laboratory characterisation of inorganic iodine emissions from the sea surface: dependence on oceanic variables and parameterisa- tion for global modelling, Atmos. Chem. Phys., 14, 5841-5852, doi:10.5194/acp-14-5841-2014, 2014.

Magi, L., Schweitzer, F., Pallares, C., Cherif, S., Mirabel, P., and George, C.: Investigation of the uptake rate of ozone and methyl hydroperoxide by water surfaces, J. Phys. Chem. A, 101, 49434949, doi:10.1021/jp970646m, 1997.

Mann, G. W., Carslaw, K. S., Spracklen, D. V., Ridley, D. A., Manktelow, P. T., Chipperfield, M. P., Pickering, S. J., and Johnson, C. E.: Description and evaluation of GLOMAP-mode: a modal global aerosol microphysics model for the UKCA composition-climate model, Geosci. Model Dev., 3, 519-551, doi:10.5194/gmd-3-519-2010, 2010.

Mao, J., Paulot, F., Jacob, D. J., Cohen, R. C., Crounse, J. D., Wennberg, P. O., Keller, C. A., Hudman, R. C., Barkley, M. P., and Horowitz, L. W.: Ozone and organic nitrates over the eastern United States: Sensitivity to isoprene chemistry, J. Geophys. Res.-Atmos., 118, 11256-11268, doi:10.1002/jgrd.50817, 2013.

Monks, P. S., Archibald, A. T., Colette, A., Cooper, O., Coyle, M., Derwent, R., Fowler, D., Granier, C., Law, K. S., Mills, G. E., Stevenson, D. S., Tarasova, O., Thouret, V., von Schneidemesser, E., Sommariva, R., Wild, O., and Williams, M. L.: Tropospheric ozone and its precursors from the urban to the global scale from air quality to short-lived climate forcer, Atmos. Chem. Phys., 15, 8889-8973, doi:10.5194/acp-15-8889-2015, 2015.

Morgenstern, O., Braesicke, P., O’Connor, F. M., Bushell, A. C., Johnson, C. E., Osprey, S. M., and Pyle, J. A.: Evaluation of the new UKCA climate-composition model - Part 1: The stratosphere, Geosci. Model Dev., 2, 43-57, doi:10.5194/gmd-2-432009, 2009.

Morris, J. C.: The aqueous solubility of ozone - A review, Ozone News, 1, 14-16, 1988.

Neu, J. L., Prather, M. J., and Penner, J. E.: Global atmospheric chemistry: Integrating over fractional cloud cover, J. Geophys. Res., 112, D11306, doi:10.1029/2006JD008007, 2007.

O’Connor, F. M., Johnson, C. E., Morgenstern, O., Abraham, N. L., Braesicke, P., Dalvi, M., Folberth, G. A., Sanderson, M. G., Telford, P. J., Voulgarakis, A., Young, P. J., Zeng, G., Collins, W. J., and Pyle, J. A.: Evaluation of the new UKCA climatecomposition model - Part 2: The Troposphere, Geosci. Model Dev., 7, 41-91, doi:10.5194/gmd-7-41-2014, 2014.

Press, W. H., Teukolsky, S. A., Vetterling, W. T., and Flannery, B. P.: Numerical Recipes in Fortran 77: the Art of Scientific Computing, 2nd Edn., Cambridge University Press, Cambridge, UK, 973 pp., 1992.

Sakamoto, Y., Yabushita, A., Kawasaki, M., and Enami, S.: Direct emission of $\mathrm{I}_{2}$ molecule and IO radical from the heterogeneous reactions of gaseous ozone with aqueous potassium iodide solution, J. Phys. Chem. A, 113, 7707-7713, doi:10.1021/jp903486u, 2009

Sarwar, G., Gantt, B., Schwede, D., Foley, K., Mathur, R., and Saiz-Lopez, A.: Impact of enhanced ozone deposition and halogen chemistry on tropospheric ozone over the Northern Hemisphere, Environ. Sci. Technol., 49, 9203-9211, doi:10.1021/acs.est.5b01657, 2015.

Sherwen, T., Evans, M. J., Carpenter, L. J., Andrews, S. J., Lidster, R. T., Dix, B., Koenig, T. K., Sinreich, R., Ortega, I., Volkamer, R., Saiz-Lopez, A., Prados-Roman, C., Mahajan, A. S., and Ordóñez, C.: Iodine's impact on tropospheric oxidants: a global 
model study in GEOS-Chem, Atmos. Chem. Phys., 16, 11611186, doi:10.5194/acp-16-1161-2016, 2016.

Smith, S. D.: Coefficients for sea surface wind stress, heat flux, and wind profiles as a function of wind speed and temperature, J. Geophys. Res., 93, 15467-15472, doi:10.1029/JC093iC12p15467, 1988.

Stevenson, D. S., Dentener, F. J., Schultz, M. G., Ellingsen, K., van Noije, T. P. C., Wild, O., Zeng, G., Amann, M., Atherton, C. S., Bell, N., Bergmann, D. J., Bey, I., Butler, T., Cofala, J., Collins, W. J., Derwent, R. G., Doherty, R. M., Drevet, J., Eskes, H. J., Fiore, A. M., Gauss, M., Hauglustaine, D. A., Horowitz, L. W., Isaksen, I. S. A., Krol, M. C., Lamarque, J.-F., Lawrence, M. G., Montanaro, V., Müller, J.-F., Pitari, G., Prather, M. J., Pyle, J. A., Rast, S., Rodriguez, J. M., Sanderson, M. G., Savage, N. H., Shindell, D. T., Strahan, S. E., Sudo, K., and Szopa, S.: Multimodel ensemble simulations of present-day and near-future tropospheric ozone, J. Geophys. Res., 111, D08301, doi:10.1029/2005JD006338, 2006.

Stevenson, D. S., Young, P. J., Naik, V., Lamarque, J.-F., Shindell, D. T., Voulgarakis, A., Skeie, R. B., Dalsoren, S. B., Myhre, G., Berntsen, T. K., Folberth, G. A., Rumbold, S. T., Collins, W. J., MacKenzie, I. A., Doherty, R. M., Zeng, G., van Noije, T. P. C., Strunk, A., Bergmann, D., Cameron-Smith, P., Plummer, D. A., Strode, S. A., Horowitz, L., Lee, Y. H., Szopa, S., Sudo, K., Nagashima, T., Josse, B., Cionni, I., Righi, M., Eyring, V., Conley, A., Bowman, K. W., Wild, O., and Archibald, A.: Tropospheric ozone changes, radiative forcing and attribution to emissions in the Atmospheric Chemistry and Climate Model Intercomparison Project (ACCMIP), Atmos. Chem. Phys., 13, 3063-3085, doi:10.5194/acp-13-3063-2013, 2013.

Telford, P. J., Braesicke, P., Morgenstern, O., and Pyle, J. A.: Technical Note: Description and assessment of a nudged version of the new dynamics Unified Model, Atmos. Chem. Phys., 8, 17011712, doi:10.5194/acp-8-1701-2008, 2008.
Uhe, P. and Thatcher, M.: A spectral nudging method for the ACCESS1.3 atmospheric model, Geosci. Model Dev., 8, 16451658, doi:10.5194/gmd-8-1645-2015, 2015.

Vingarzan, R.: A review of surface ozone background levels and trends, Atmos. Environ., 38, 3431-3442, doi:10.1016/j.atmosenv.2004.03.030, 2004.

von Kuhlmann, R., Lawrence, M. G., Crutzen, P. J., and Rasch, P. J.: A model for studies of tropospheric ozone and nonmethane hydrocarbons: Model description and ozone results, J. Geophys. Res., 108, 4294, doi:10.1029/2002JD002893, 2003.

Wanninkhof, R.: Relationship between wind speed and gas exchange over the ocean, J. Geophys. Res., 97, 7373-7382, doi:10.1029/92JC00188, 1992.

Wesely, M.: Parameterization of surface resistances to gaseous dry deposition in regional-scale numerical-models, Atmos. Environ., 23, 1293-1304, doi:10.1016/0004-6981(89)90153-4, 1989.

Wild, O.: Modelling the global tropospheric ozone budget: exploring the variability in current models, Atmos. Chem. Phys., 7, 2643-2660, doi:10.5194/acp-7-2643-2007, 2007.

Woodhouse, M. T., Luhar, A. K., Stevens, L., Galbally, I., Thatcher, M., Uhe, P., Wolff, H., Noonan, J., and Molloy, S.: Australian reactive-gas emissions in a global chemistry-climate model and initial results, Air Quality and Climate Change, 49, 31-38, 2015.

Young, P. J., Archibald, A. T., Bowman, K. W., Lamarque, J.-F., Naik, V., Stevenson, D. S., Tilmes, S., Voulgarakis, A., Wild, O., Bergmann, D., Cameron-Smith, P., Cionni, I., Collins, W. J., Dalsøren, S. B., Doherty, R. M., Eyring, V., Faluvegi, G., Horowitz, L. W., Josse, B., Lee, Y. H., MacKenzie, I. A., Nagashima, T., Plummer, D. A., Righi, M., Rumbold, S. T., Skeie, R. B., Shindell, D. T., Strode, S. A., Sudo, K., Szopa, S., and Zeng, G.: Preindustrial to end 21st century projections of tropospheric ozone from the Atmospheric Chemistry and Climate Model Intercomparison Project (ACCMIP), Atmos. Chem. Phys., 13, 2063 2090, doi:10.5194/acp-13-2063-2013, 2013. 